Otto et al. (2019): Futurelakes - Final Report 


\section{Formation and future evolution of glacier lakes in Austria (FUTURELAKES)}

Final Report

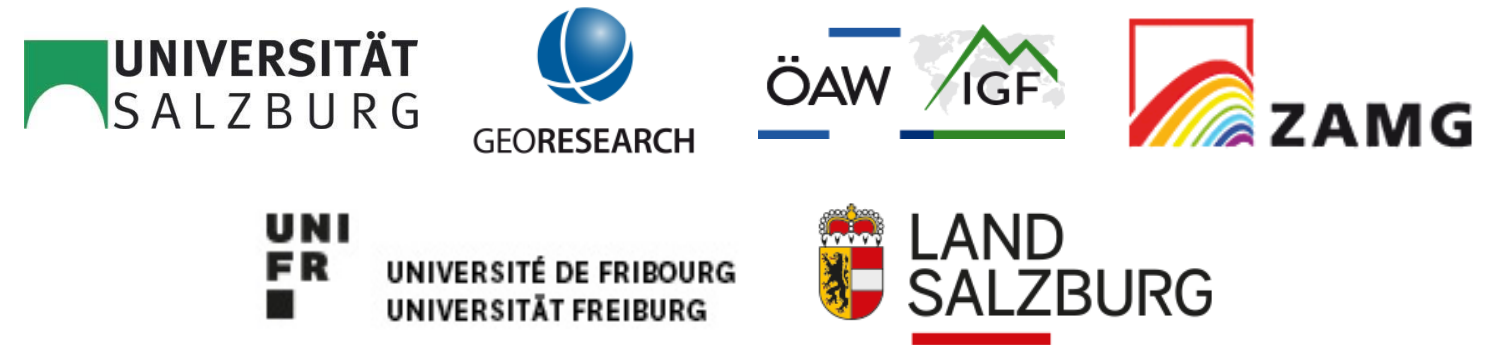


Otto et al. (2019): Futurelakes - Final Report

Authors:

Jan-Christoph Otto, Kay Helfricht, Günther Prasicek, Markus Keuschnig,

Citation:

Otto, J.-C., Helfricht, K., Prasicek, G. \& Keuschnig, M. (2019): Formation and future evolution of glacier lakes in Austria (FUTURELAKES). FINAL REPORT to the Austrian Academy of Sciences (ÖAW). Vienna, DOI: 10.1553/ESS-Future_Lakes

ISBN-Online: 978-3-7001-8423-2

DOI: 10.1553/ESS-Future_Lakes 


\section{Table of Contents}

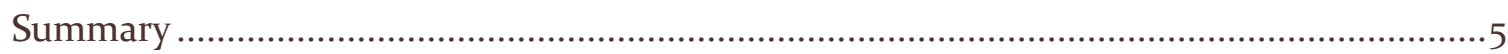

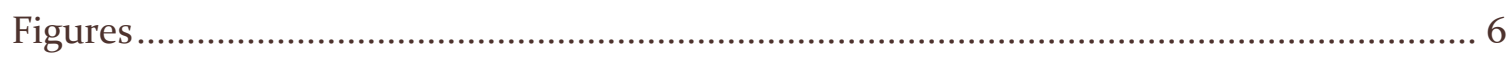

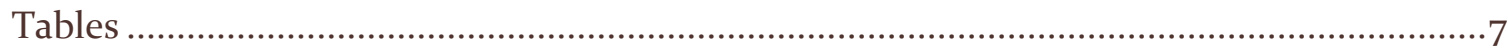

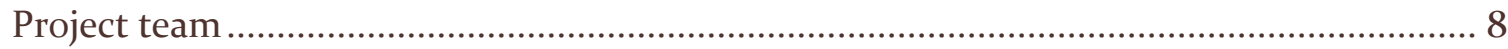

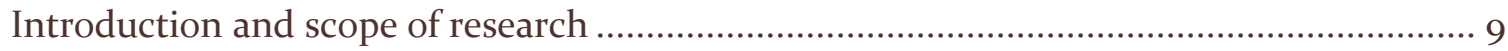

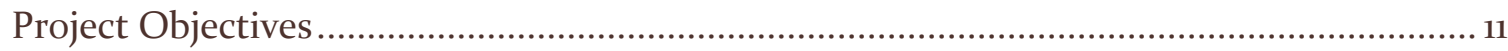

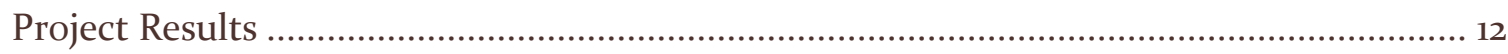

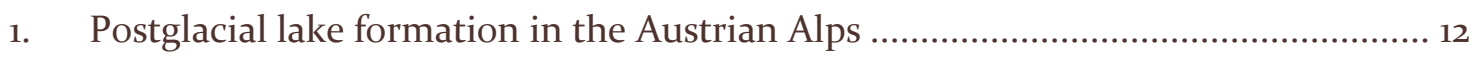

2. Modelling of future glacier lake formation in Austria ................................................15

2.1 Manual classification using morphological criteria (MC) ...................................15

2.2 Modelling glacier ice thickness and deriving subglacial depressions .................. 17

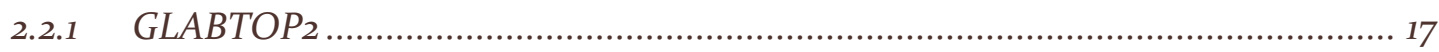

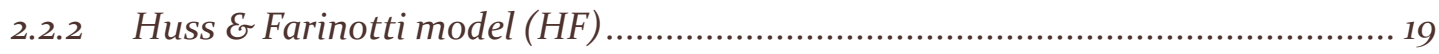

2.2.3 Potential new lakes underneath the current glacier extent .................................20

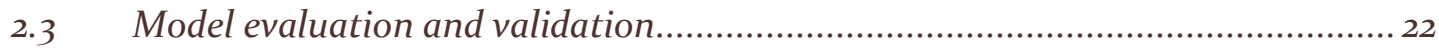

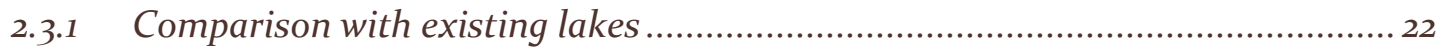

2.3.2 Model results versus field data ...........................................................................24

2.3.3 An alternative approach to estimate potential new lakes ....................................30

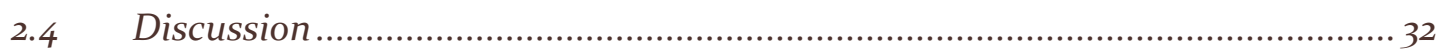

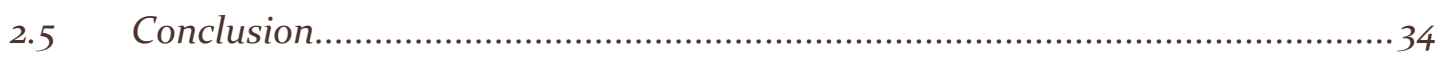

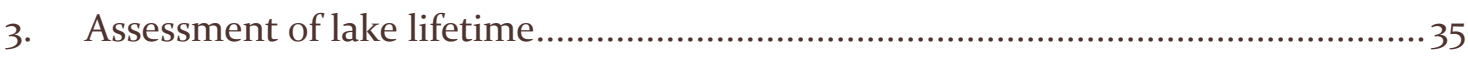

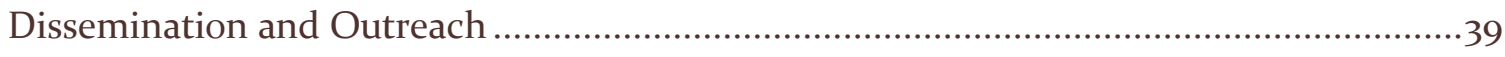

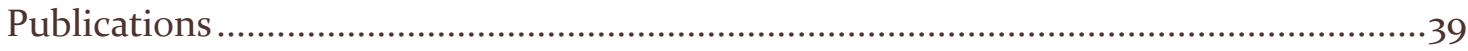

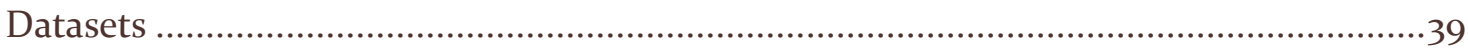

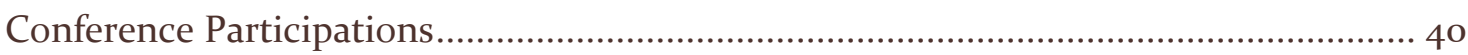

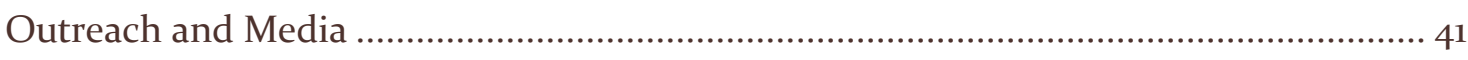

Acknowledgements .............................................................................................

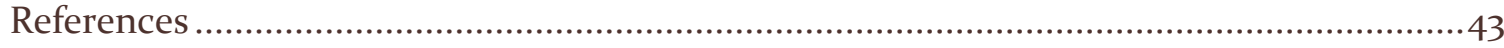




\section{Summary}

The European Alps, like most mountain environments, are experiencing significant landscape changes as a reaction to climate change. The most visible manifestation of these changes is widespread glacier melt and the release of new terrain in high mountain areas. Within this terrain new lakes may form. Glacial lakes can constitute an important environmental and socio-economic impact on high mountain systems including water resource management, sediment delivery, natural hazards, energy production, and tourism. Their development significantly modifies the landscape configuration and visual appearance of high mountain areas.

Futurelakes investigated the past, current and future formation of glacial lakes in Austria. The scope of the project was to generate a data base on current and future glacier lakes for Austria as knowledge base for further investigations on geomorphological, hydrological and socio-economic effects of glacier lakes. We mapped existing high alpine lakes in Austria and analyzed formation dynamics since the Little Ice Age. We applied different glaciological models for modelling of the subglacial topography, which hosts depressions that may form into future lakes. Finally, we studied sedimentation dynamics in a recently formed glacial lake in order to assess the potential lifetime of this new lake.

In Austria, more than 1400 lakes exist in high alpine locations. A distinct pattern of lake density is apparent, with increasing number of lakes towards the East. More than 260 new lakes have formed in glacier forefields since the Little Ice Age. The rate of formation of new glacial lakes has continuously accelerated over time with present rates showing an eightfold increase since LIA. The total glacier area decreased by two-thirds within the same period. This development coincides with a long-term trend of rising temperatures and a significant stepping up of this trend within the last 20 years in the Austrian Alps. Consequently, we conclude that formation of glacier lakes can be regarded as an indicator of climate change in high mountains.

Models predict a total area between 4 and $10 \mathrm{~km}^{2}$ that may evolve into potential new lakes from the current glacier surface. Considering a mean lake size between 12,000 and 50,000 $\mathrm{m}^{2}$, between 130 and 260 new lakes may appear until 2100. However, the applied modelling approaches contain large uncertainties. Models do not represent the subglacial topography with great accuracy and reliability. Uncertainties of the modelling approach are difficult to assess and models provide only limited possibilities for calibration and adaptation. A detailed localization of future glacier lakes is therefore difficult and requires more field evaluation. The modelling results hence only represent a rough estimation of the total size of potential new lakes.

In our field study we produced a high resolution image of lake sediments derived from various geophysical surveying techniques. We traced the sedimentary conditions during the retreat of the glacier snout from the lake and most recent sedimentation dynamics of the delta and the lake bottom. Assuming an ongoing rate of sediment delivery and deposition we estimate a total filling of the lake within the next 20-30 years. However, a decrease in sediment delivery is possible with increase of distance between glacier front and lake. 
Otto et al. (2019): Futurelakes - Final Report

\section{Figures}

Figure 1 Glacier lakes at Hochjochferner, Ötztal, Tirol

Figure 2 Lake density $(\mathrm{m} 2 / \mathrm{km} 2)$ derived from dividing lake area above $1700 \mathrm{~m}$ a.s.l. by terrain area above $1700 \mathrm{~m}$ a.s.l.; calculation based on a moving window with a size of $20 \times 20$ $\mathrm{km}$. Numbers label mountain ranges mentioned in the text: (1) Stubaier Alps, (2) Tuxer and Zillertaler Alps, (3) Venediger group, (4) Ankogel group, (5) Schladminger Tauern (from Buckel et al. 2018).

Figure 3 Relative distribution of lake number, lake area and total area over elevation. (from: Buckel et al. 2018)

Figure 4 (A) Distribution of all dam types over elevation. The class "debris cone-dammed" combines the different depositional landforms involved. (B): The distribution of dam types over elevation within the LIA extent. Data is binned into $100 \mathrm{~m}$ altitude levels. (from: Buckel et al. 2018)

Figure 5 Number and area of new lakes since LIA (black lines) and the average new lake area per year (gray bars). Dashed vertical lines mark the end of each formation period. (Data from this study and Fischer et al. (2015a) (from: Buckel et al. 2018)

Figure 6 Manual classification of potential future glacier lakes using morphological criteria. (A) Mapped locations with 1, 2, or 3 of the MC in place for the GI 1 glacier extent. (B) Same classification for the GI 3 glacier extent.

16

Figure 7 (A) Relative changes in volume and area from GI 1 and GI 2 to the latest glacier inventory (GI 3). (B) Total volume of all glaciers in the respective mountain ranges. The five smallest volumes are less than $0.01 \mathrm{~km}^{3}$. Regions are ordered according to increasing ice volume (from Helfricht et al., submitted)

Figure 8 Modelled subglacial depressions for the Großglockner area with Pasterze glacier in the center. Depressions have been clipped to the current (2015) glacier extent.

Figure 9 Modelling results for the Großvenediger range. While the proglacial lake in the Obersulzbach valley (red circle on the top right) is reproduced to a certain extent by all models, the lake in the neighboring Krimmler valley (red circle on the left) is not predicted by any tested modelling approach.

Figure 1o Comparing modelled ice thickness values with measured values collected by lowfrequency GPR for a selected number of glaciers (6oo measurement on 16 glaciers, data from Fischer et al. (2015b)).

Figure 11 Longitudinal profiles of GPR measurements at Schmidingerkees.

Figure 12 Longitudinal profiles of GPR measurements at (A) Kleinfleisskees and (B ,C) Wurtenkees.

Figure 13 Comparing slope-thickness relationships between field (GPR) and model data (GLABTOP2) for Schmidingerkees (A), Ödenwinkelkees (B), Kleinfleisskees (C) and Wurtenkees (D). Slope value is extracted from the GLABTOP2 model. 
Figure 14 Plotting trends of emerging lake area with glacier retreat. The linear prognosis refers to a continuation of glacier retreat applying the mean melt rate between 2006 and 2015. Other scenarios of glacier melt are taken from Zekollari et al. (2018).

Figure 15 Lake Sulzsee in Obersulzbachtal, Hohe Tauern. Left: Lake position in 2009 (spring). Icebergs and supraglacial debris is observable on the frozen lake surface. The glacier front is still in contact with the lake, observable in the distal right part of the lake. Right: Lake position in 2018 (summer). The glacier terminus retreated from lake area completely.

Figure 16 Longitudinal cross section of the lake bottom of lake Sulzsee, Obersulzbachtal, Austria, derived from repeated echo sounding and SBB profiling between 2009 and 2018. Reference lake level is $2202 \mathrm{~m}$.

Figure 17 Radargram of delta area at lake Sulzsee, showing the declining bedrock interface clearly visible underneath the sediment filling of the lake. Single boulders and inclined linear structure in the reflection pattern indicate delta type sedimentation. Data was acquired using a $100 \mathrm{MHz}$ antenna and a $1 \mathrm{~m}$ trace interval.

Figure 18 Bathymetry changes between 2009 and 2015 of the lake Sulzsee, Obersulzbachtal, Austria. Lake bottom decrease is interpreted as settling and melt of covered ground ice. Bathymetry increase reflects deposition.

\section{Tables}

Table 1 Comparing potential lake locations using MC and the models.

Table 2 Parameter of GLABTOP2 model (Frey et al., 2014) and tested variations.

Table 3 Results of subglacial depressions modelling for the two time steps and both modelling approaches.

Table 4 Total number of potential new lakes in Austria within glacier area of 2015 (GI4). 22

Table 5 Comparison of existing lakes and modelled lakes.

Table 6 Ratio between emerged lake area per year and area released by glacier melt per year (data from Buckel et al. (2018); Fischer et al. (2015a)).

Table 7 Potential future cumulative release area by glacier melt and potential total cumulative new lake area based on the extrapolation approach described. 
Project team

\section{University of Salzburg}

Ass.-Prof. Dr. Jan-Christoph Otto (PI, Project leader)

Dr. Günther Prasicek

Johannes Buckel, Msc.

Milena Kocher, Bsc.

Christopher Hausmann, Bsc.

\section{Georesearch Forschungsgesellschaft mbH \\ Dr. Markus Keuschnig (PI)}

Institute of Interdisciplinary Mountain Research Austrian Academy of Sciences

Dr. Kay Helfricht

PD Mag. Dr. Andrea Fischer

Zentralanstalt für Meteorologie und Geodynamik

Daniel Binder, Msc.

University of Fribourg

Dr. Matthias Huss

\section{Advisory Partner:}

Hydrographischer Dienst, Land Salzburg

Dipl.-Ing. Johannes Wiesenegger

\section{UNIVERSITÄT S A L Z B U R G}
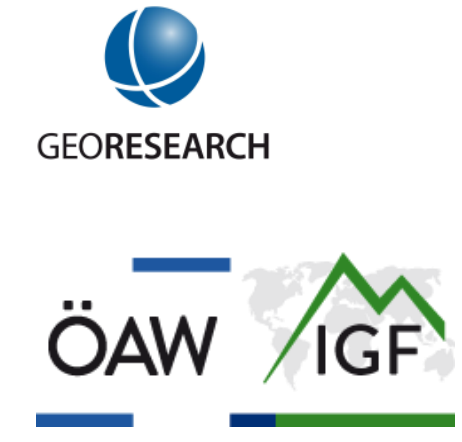
UNIVERSITÃT FREIBURG 


\section{Introduction and scope of research}

The European Alps, like most mountain environments, are experiencing significant landscape changes as a reaction to ongoing climate change. Shrinking glaciers in the 2oth and early 21st century are the most visible manifestation of these changes leading to the exposure of new terrain, an increase in unconsolidated sediment deposits, and the reduction of ice and water resources in high alpine regions. One frequent consequence of glacier disappearance is the formation of glacial lakes (Carrivick and Tweed, 2013; Haeberli et al., 2016). In Austria, more than 260 new lakes have formed in glacier forefields since the Little Ice Age (Buckel et al., 2018). A similar signal is reported from many mountain areas of the world (Cook et al., 2016; Emmer et al., 2015; Gardelle et al., 2011; Mergili et al., 2013; Pelto et al., 2013; Song et al., 2016; Wang et al., 2014; Zhang et al., 2015).

Glacial lakes can constitute an important environmental and socio-economic impact on high mountain systems including water resource management, sediment delivery, natural hazards, energy production, and tourism. Their development significantly modifies the landscape configuration and visual appearance of high mountain areas. Due to their potential to create hazardous glacier lake outburst floods (GLOFS), glacial lakes are in focus of geomorphological research in many high mountain areas (Clague and O'Connor, 2015; Kapitsa et al., 2017a; O'Connor and Costa, 2004). However, they also affect hydrological, sedimentological, and socio-economical systems (Haeberli et al., 2016). Increasing public awareness of climate change and related hazards, as well as scientific interest from landscape evolution studies, has put glacial lakes in the spotlight of current high mountain research. Knowledge on the location, number, and extent of future lakes can be used to assess potential impacts on the high mountain geo-ecosystems and upland-lowland

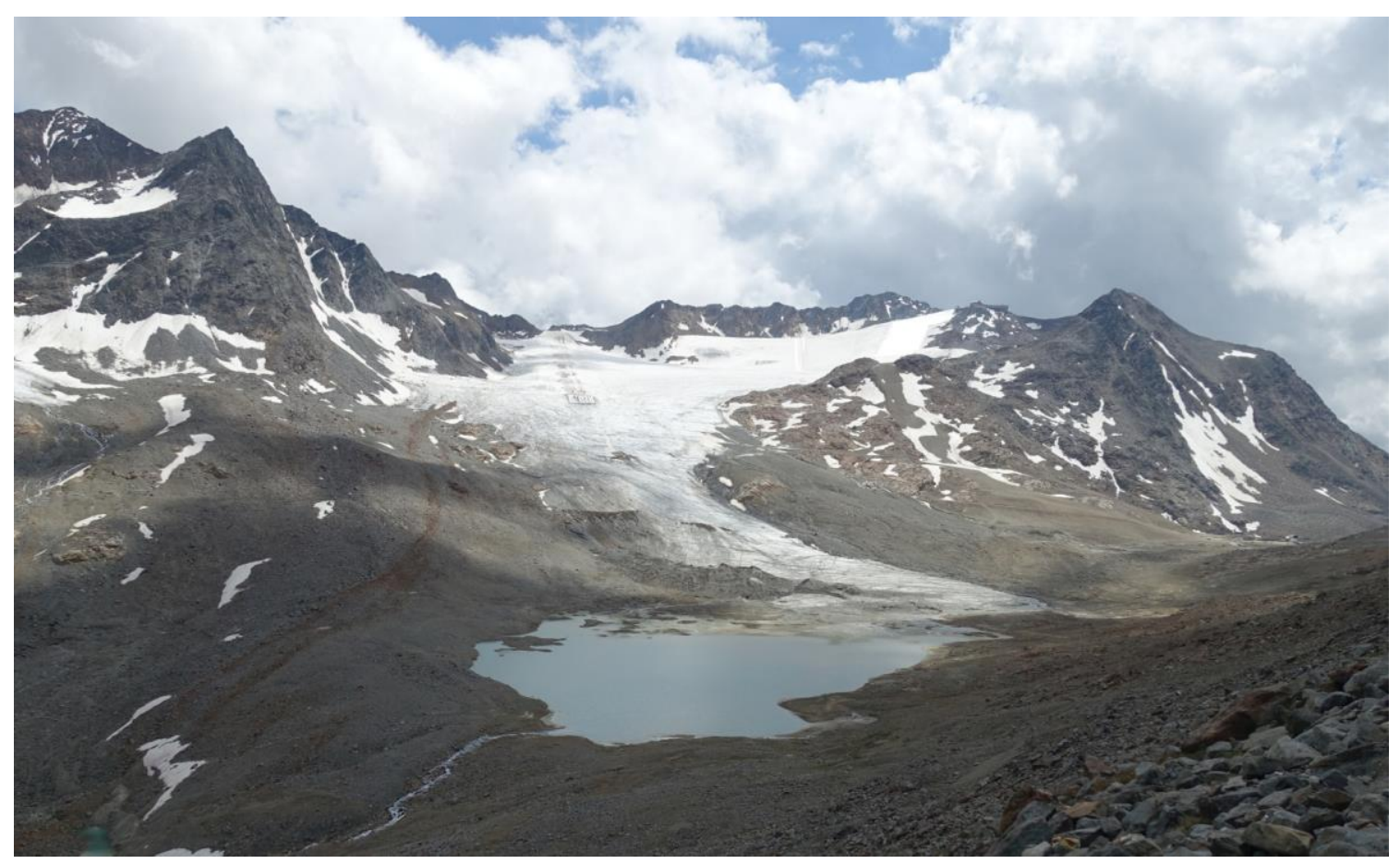

Figure 1 Glacier lakes at Hochjochferner, Ötztal, Tirol 
interactions. This information is crucial to appraise threads and potentials of the new lakes for society.

The formation of glacial lakes is the result of glacier retreat exposing a topographic bedrock depressions or space behind a dam inhibiting runoff and provoking storage of water and sediment (Otto 2018). They are common landscape elements in high mountain environments (Messager et al., 2016). Glacial lakes thus are first order sediment sinks and interrupt the sediment cascade and sediment transfer dynamics from uplands to lowlands. The stored sediment represents an important sedimentary archive enabling reconstruction of glacier conditions in the lake catchment and past climatic conditions of the mountain range (Blass et al., 2007; Larsen et al., 2011; Leemann and Niessen, 1994). Proglacial lakes at glacier margins positively feedback on the glacier system resulting in increased ice velocities, changed mass balances, and enhanced melting (Carrivick and Tweed, 2013).

Recent developments in combining ice thickness models with high-resolution glacier surface data allow generating models of the future, ice-free bedrock topography below current glaciers (Farinotti et al., 2017; Frey et al., 2010b; Linsbauer et al., 2012b). The analysis of these potential glacier beds reveals bedrock depressions, termed overdeepenings, which represent potential locations for future lakes (Cook and Swift, 2012). Modelling of potential glacial lakes has been performed for selected mountain regions and even large ice shields (Colonia et al., 2017a; Frey et al., 2010b; Kapitsa et al., 2017a; Linsbauer et al., 2016b; Linsbauer et al., 2012b; Livingstone et al., 2013; Patton et al., 2016). Potential lakes underneath mountain glaciers have been predicted by analyzing morphometric criteria of the glacier surface that indicate potential locations for glacial lake formation (Colonia et al., 2017a; Frey et al., 2010a). These criteria include for example low slope (e.g. $<5^{\circ}$ ), increasing slope in flow direction, formation of crevasses, or a reduction in glacier width. This approach requires a mostly manual classification of glacier morphology and thus fails to allow predictions of a larger number of glaciers. More automated approaches use ice thickness models to derive the potential subglacial topography, or use existing digital elevation models of the bedrock surface, in order to identify the location of topographic depressions (Linsbauer et al., 2016a; Linsbauer et al., 2012b; Livingstone et al., 2013; Patton et al., 2015). Based on the assumption that the bedrock surface beneath glaciers is reflected in the shape of the glacier surface, quantification of the ice thickness allows generating the potential subglacial morphology. Paul and Linsbauer (2012) back up this assumption by postulating that current glaciers contribute less to bedrock erosion compared to glaciers during the major glaciations. Consequently, current glaciers rather fill the previously carved bedrock surface thus portraying the bedrock morphology.

The modelling approach most frequently used to predict potential future lakes is the GLABTOP model of (Linsbauer et al., 2009). The model has been further developed by Paul and Linsbauer (2012) and as GLABTOP2 by Frey et al. (2013). GLABTOP was applied to model potential glacier lakes in Switzerland (Linsbauer et al., 2012b), the HimalayaKarakorum region (Linsbauer et al., 2016a), the Djungarskiy Alatau, Kasachstan/China border (Kapitsa et al., 2017b), and the Peruvian Andes (Colonia et al., 2017a). In order to assess the quality of these predictions, the modelled ice thickness is compared to field data usually derived from geophysical surveying. The accuracy of GLABTOP is reported to be within a range of $+/-30 \%$ (Linsbauer et al., 2016a; Linsbauer et al., 2012b), which is in 
accordance with other ice thickness models (Farinotti et al., 2017). Additionally, predicted lakes can be compared to existing lakes, when ice thickness modelling is performed using topographic data of previous glacier extents (Kapitsa et al., 2017b; Linsbauer et al., 2016a). For the latter however, lake siltation needs to be acknowledged that may reduce the number of existing lakes and add uncertainty to the prediction results.

Futurelakes relied on these previous approaches and applied different glaciological models to glaciers in the Austrian Alps for the assessment of future glacier lakes. The scope of the project was to generate a data base on current and future glacier lakes for Austria as knowledge base for further investigations on geomorphological, hydrological and socioeconomic effects of glacier lakes.

\section{Project Objectives}

The project started with an assessment of past lake formation leading to the compilation of a lake inventory database. The focus of the project was on modelling of subglacial topography for the detection of potential future lakes underneath the current glacier extent. Furthermore, the issue of glacier lake formation was analyzed and discussed with respect to geomorphological setting and expected lifetime of new lakes.

The project had three main objectives:

- Assess current and past extend of glacier lakes formation in the Austrian Alps (Task 1 ).

- Model potential overdeepenings underneath Austrian glaciers and relate them to lake formation (Task 2).

- Analyze geomorphological conditions of lake formation and lake evolution (Task 3). 


\section{Project Results}

\section{POSTGLACIAL LAKE FORMATION IN THE AUSTRIAN ALPS}

\section{Publications:}

Buckel, J., Otto, J.C., Prasicek, G. and Keuschnig, M., 2018. Glacial lakes in Austria - Distribution and formation since the Little Ice Age. Global and Planetary Change, 164, 39-51. /10.1016/j.gloplacha.2018.03.003

Data Set: Buckel, J; Otto, J-C (2018): Inventory of glacial lakes in Austria (elevation >1700m). https://doi.org/10.1594/PANGAEA.885931

Data Set: Buckel, J; Otto, J-C (2018): The Austrian Glacier Inventory GI 4 (2015) in ArcGis (shapefile) format. https://doi.org/10.1594/PANGAEA.887415

Glacial lakes constitute a substantial part of the legacy of mountain glaciation and act as water storage, sediment traps, and sources of both natural hazards and leisure activities. For these reasons, they receive growing attention by scientists and society. However, while the evolution of glacial lakes has been studied intensively over timescales tied to remote sensing-based approaches, the longer-term perspective has been omitted due a lack of suitable data sources. We mapped and analyzed the spatial distribution of glacial lakes in the Austrian Alps (Figure 2). A distinct pattern of lake density is apparent in Austria, with an increasing number of lakes towards the East. The highest concentration of lakes is observed in the Venediger Tauern, the Großglockner area and the Schladminger Tauern. Most lake area is located between 2000 and $2700 \mathrm{~m}$ with the greatest number of lakes around $2500 \mathrm{~m}$ (Figure 3 ). We trace the development of number and area of glacial lakes in the Austrian Alps since the Little Ice Age (LIA) based on a unique combination of a lake and dam inventory and an extensive record of glacier retreat (Figure 4). We find that bedrock-dammed lakes are the dominant lake type in the inventory. Bedrock- and morainedammed lakes populate the highest landscape domains located in cirques and hanging valleys. Lakes embedded in glacial deposits were observed at lower locations below $2000 \mathrm{~m}$. In general, the distribution of glacial lakes over elevation reflects glacier erosional and depositional dynamics rather than the distribution of total area. The rate of formation of new glacial lakes (number, area) has continuously accelerated over time with present rates showing an eight-fold increase since LIA (Figure 5). The total glacier area decreased by twothirds within the same period. This development coincides with a long-term trend of rising temperatures and a significant stepping up of this trend within the last 20 years in the Austrian Alps. Consequently, we conclude that formation of glacier lakes can be regarded as an indicator of climate change in high mountains. 


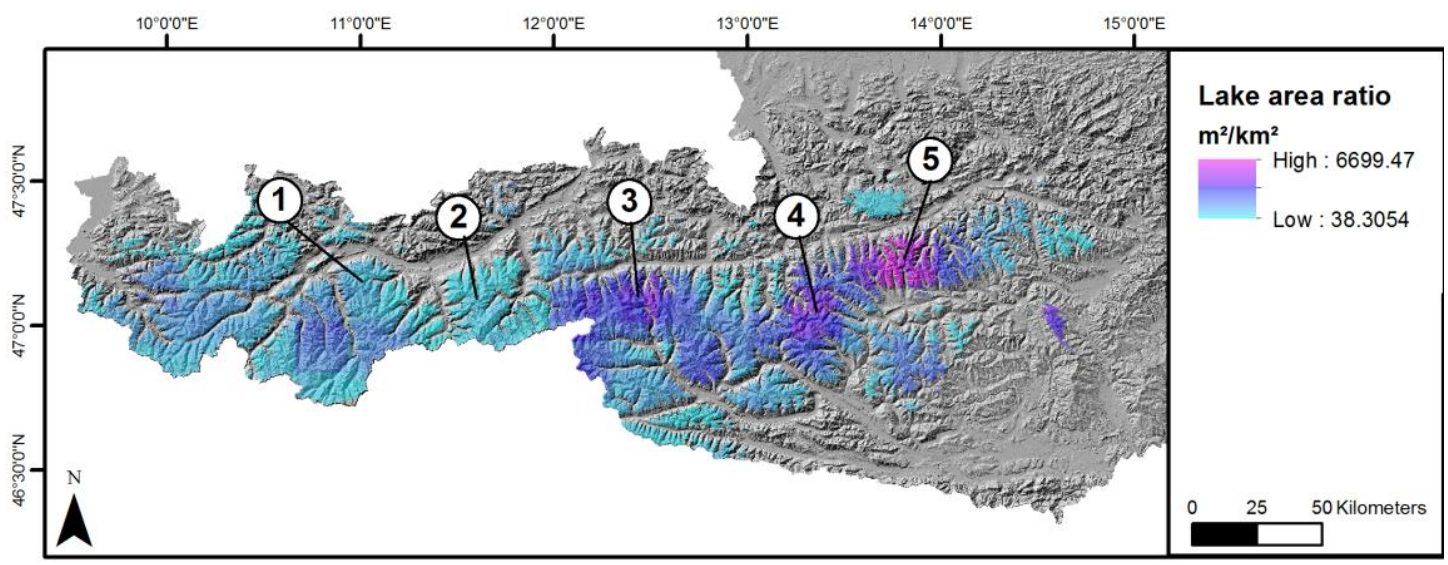

Figure 2 Lake density ( $\mathrm{m} 2 / \mathrm{km} 2)$ derived from dividing lake area above $1700 \mathrm{~m}$ a.s.l. by terrain area above $1700 \mathrm{~m}$ a.s.l.; calculation based on a moving window with a size of $20 \times 20 \mathrm{~km}$. Numbers label mountain ranges mentioned in the text: (1) Stubaier Alps, (2) Tuxer and Zillertaler Alps, (3) Venediger group, (4) Ankogel group, (5) Schladminger Tauern (from Buckel et al. 2018).

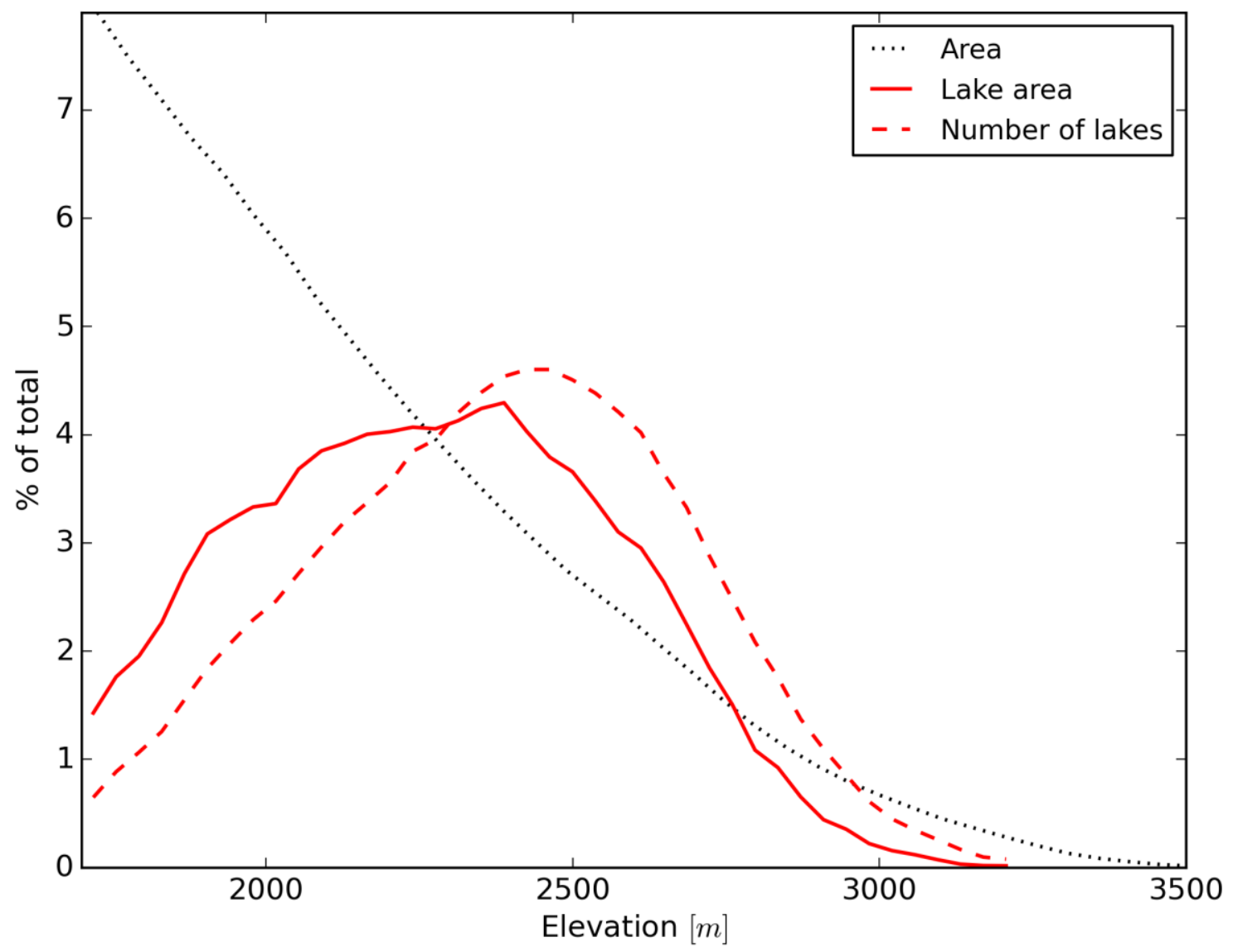

Figure 3 Relative distribution of lake number, lake area and total area over elevation. (from: Buckel et al. 2018) 

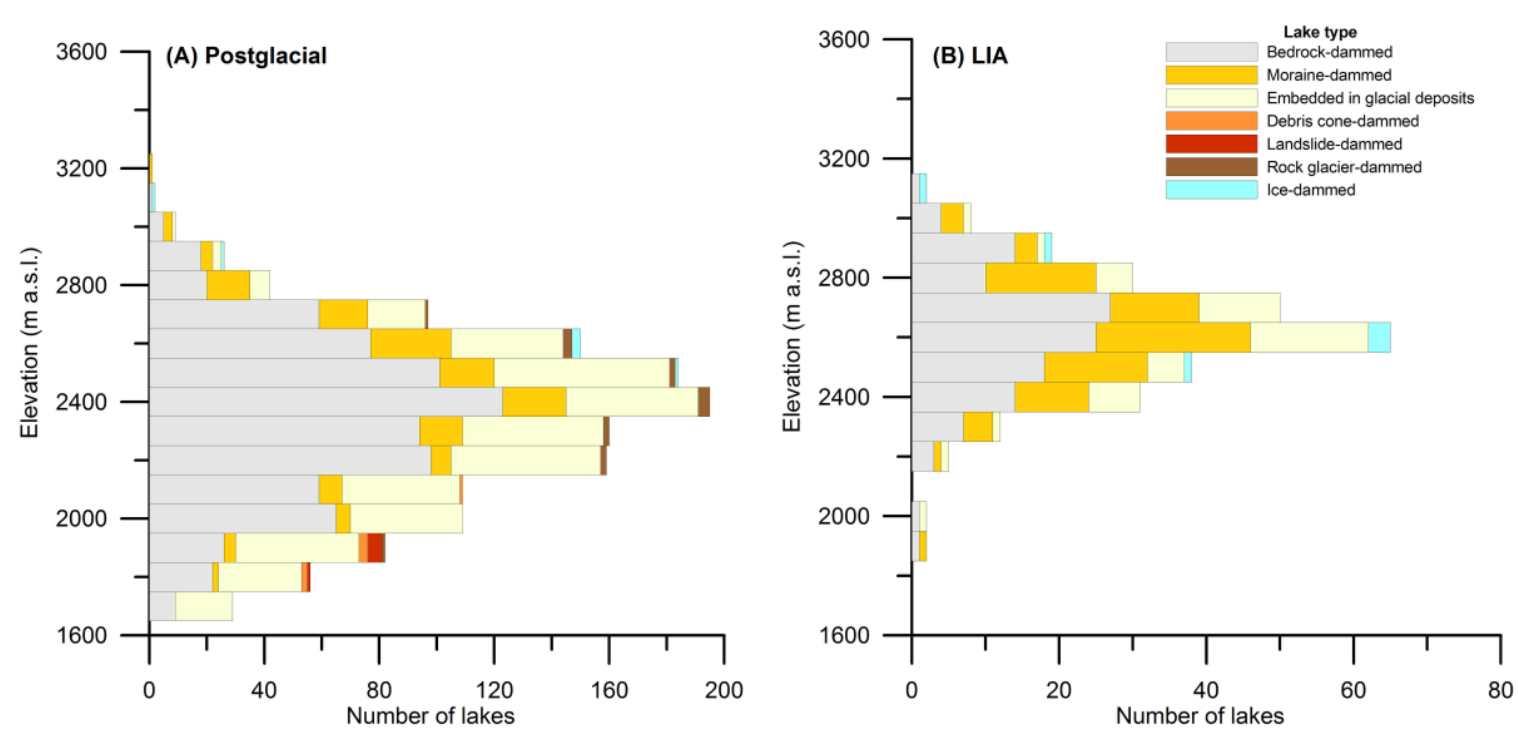

Figure 4 (A) Distribution of all dam types over elevation. The class "debris cone-dammed" combines the different depositional landforms involved. (B): The distribution of dam types over elevation within the LIA extent. Data is binned into $100 \mathrm{~m}$ altitude levels. (from: Buckel et al. 2018)

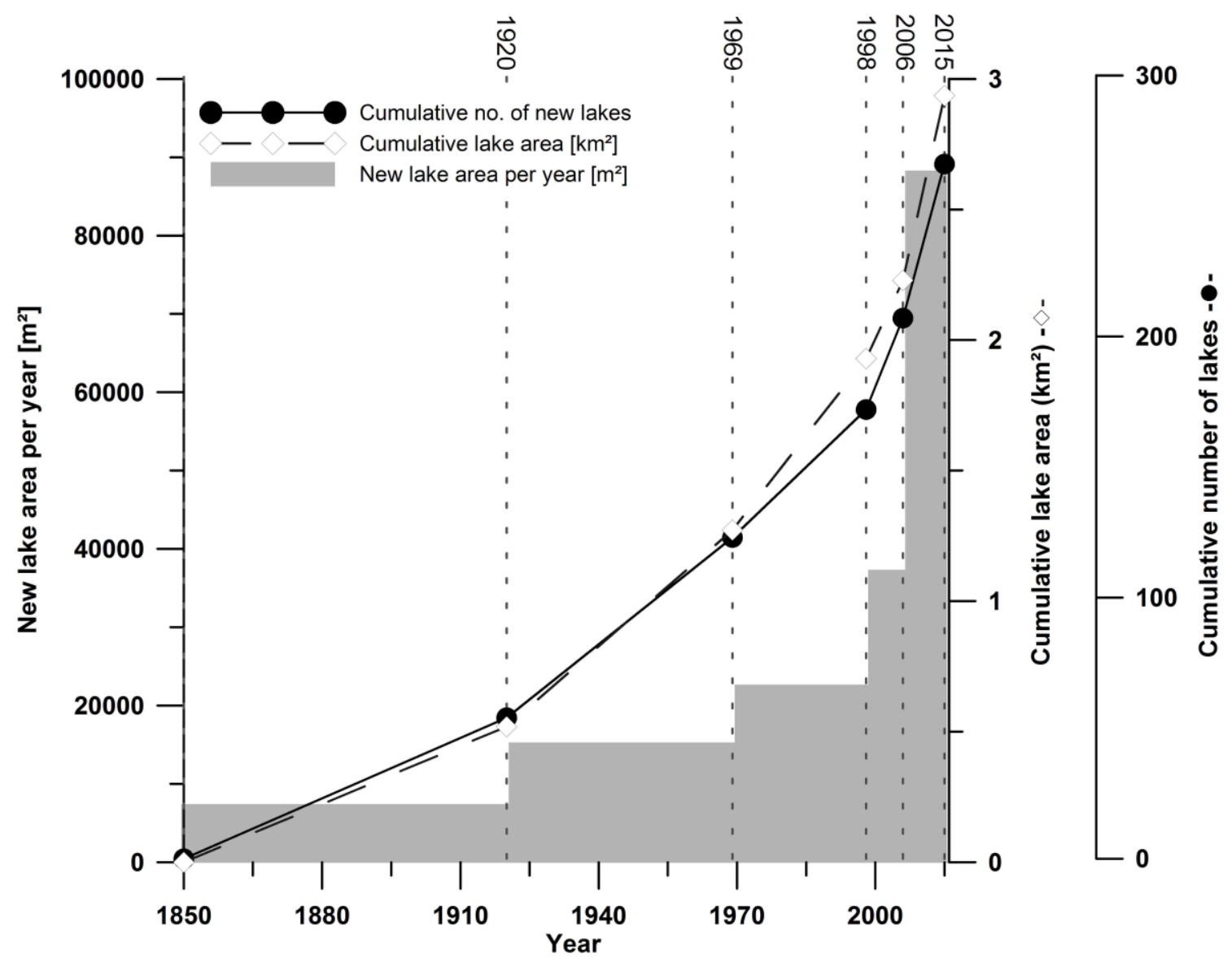

Figure 5 Number and area of new lakes since LIA (black lines) and the average new lake area per year (gray bars). Dashed vertical lines mark the end of each formation period. (Data from this study and Fischer et al. (2015a) (from: Buckel et al. 2018) 


\section{Publications:}

Helfricht, K., Huss, M., Fischer, A. and Otto, J.-C. (in review). Calibrated ice thickness estimate for all glaciers in Austria. Submitted to: Frontiers in Earth Science.

Otto, J.C., Helfricht, K, Prasicek, G. and Keuschnig, M. (in preparation): Modelling the potential future formation of glacial lakes in Austria.

Task 2 aimed at modelling the potential number, size, and volume of future glacier lakes underneath the current glacier extent of Austria. A key aspect of this task was to compare and discuss different modelling approaches and to use high-resolution field data on ice thickness for model validation. The procedure to predict potential lake locations underneath Austria's glaciers involved several steps:

(1) Manual classification following previously stated morphological and morphometrical criteria (MC) (Frey et al. 2010): (i) distinct slope increase, (ii) reduction of glacier width, and (iii) crevasse-free part followed by heavily crevassed part

(2) Modelling of glacier thickness at different glacier extents $(1969,2012)$ based on:

a. GLABTOP2 model (GL2) (Frey et al., 2014)

b. Huss \& Farinotti model (HF) (Helfricht et al., submitted; Huss and Farinotti, 2012);

Derivation of subglacial depressions by subtraction of ice thickness from ice surface, and sink detection on glacier bed DEM.

(3) Model evaluation and validation using:

a. Austrian lake inventory compared to modelling of 1969 ice thickness

b. Comparison of modelled ice thickness/glacier bed morphology with ground penetrating radar (GPR) data

\subsection{Manual classification using morphological criteria (MC)}

A manual classification of potential future glacier lakes required the visual inspection of glaciers on aerial imagery. To validate the potential of this method a subset of the Austrian glaciers was chosen, focusing on the Ötztal mountain range. This region was chosen due to the good availability of current and historical orthoimages. We mapped the morphological criteria at two points in time in accordance to the glacier inventories (GI) using images from 1969 (GI 1) and from 2012 (GI3). The region contains 67 glaciers in the upper Ötztal and Pitztal valleys (Figure 6). At 97 locations within the GI 1 glacier extent and at 54 locations within the GI 3 extent at least one of the MC have been observed. For 16 locations (GI 1) all three criteria apply, indicating a higher probability for potential subglacial depressions (cf. Colonia et al., 2017b). Compared to the modelling results, we observe that the manual approach identifies an equal number of locations as potential subglacial depressions (Table 1). However, the matching between locations derived using the MC and modelled positions 
is quite poor. Between 5 and $30 \%$ of the locations identified by the MC match locations generated by the models (Table 1 ).
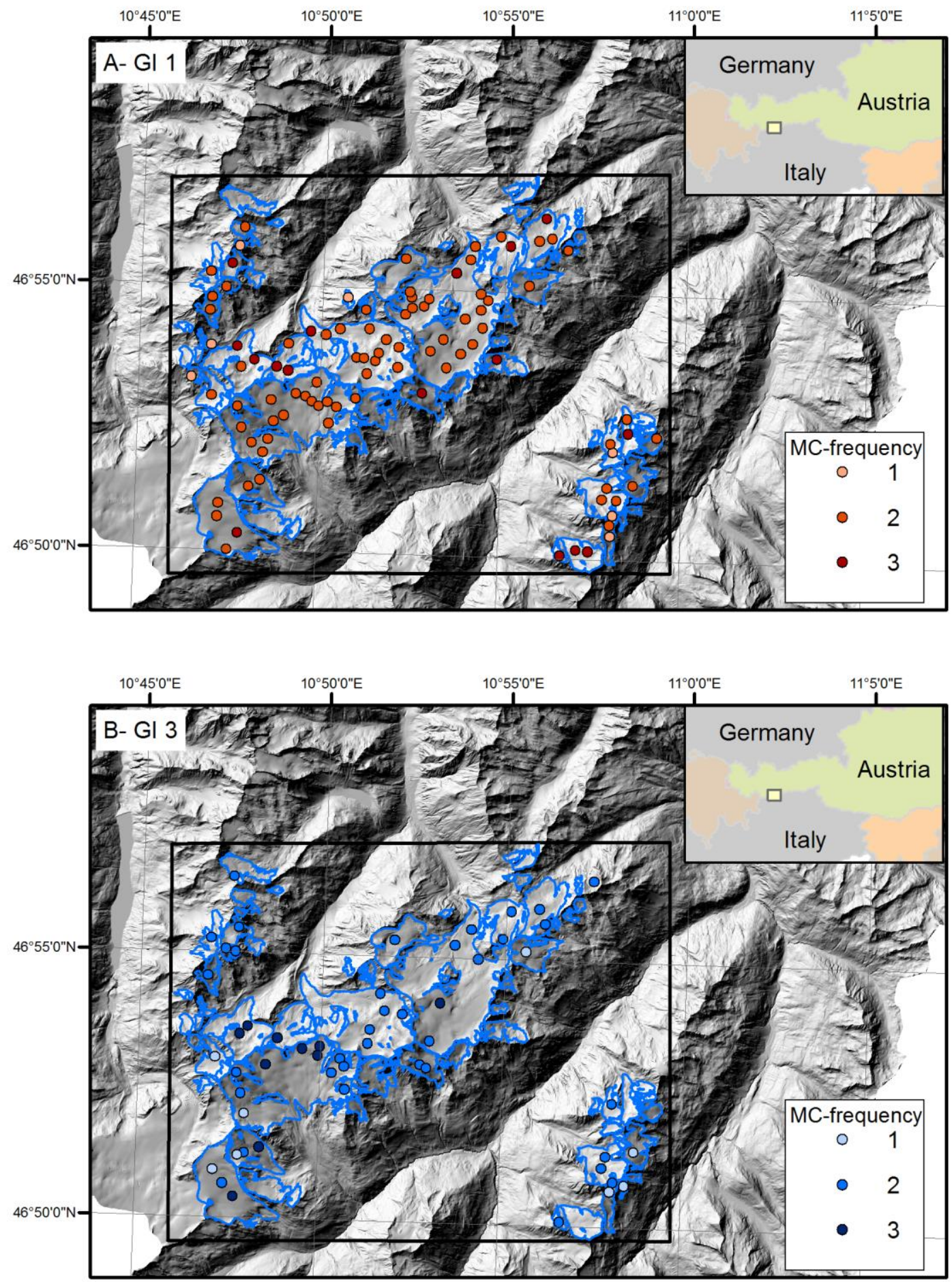

Figure 6 Manual classification of potential future glacier lakes using morphological criteria. (A) Mapped locations with 1, 2, or 3 of the MC in place for the GI 1 glacier extent. (B) Same classification for the GI 3 glacier extent. 
Otto et al. (2019): Futurelakes - Final Report

Table 1 Comparing potential lake locations using MC and the models.

\begin{tabular}{llll} 
GI & No. of lakes MC & $\begin{array}{l}\text { No. of lakes of GL2 } \\
\text { matching } \\
\text { total GL2 }\end{array}$ & $\begin{array}{l}\text { No. of lakes of HF matching MC / } \\
\text { total HF }\end{array}$ \\
\hline 1 & 97 & $13 / 124$ & $16 / 54$ \\
3 & 54 & $18 / 129$ & $3 / 34$
\end{tabular}

\subsection{Modelling glacier ice thickness and deriving subglacial depressions}

We applied two different ice thickness models for the automated detection of future glacier lakes: the GLABTOP2 model (Frey et al., 2014) and the Huss \& Farinotti model (HF-model, Helfricht et al. (submitted); Huss and Farinotti (2012)). In both approaches, ice thickness is modelled and then subtracted from the ice surface to obtain the bedrock surface. This technique is based on the assumption that the bedrock surface beneath current glaciers is reflected in the shape of the glacier surface. Paul and Linsbauer (2012) support this assumption by postulating that current glaciers contribute less to bedrock erosion compared to glaciers during the major glaciations. Consequently, current glaciers rather fill the previously carved bedrock surface thus portraying the bedrock morphology. The method only allows to predict glacier lakes forming in bedrock depressions without accounting for debris-covered glacier beds. Other types of lakes, such as moraine-dammed lakes, cannot be predicted. In a final step, subglacial depressions in the modelled bedrock DEM are delimited with a fill-sinks algorithm (following Linsbauer et al., 2012b). Modelling was performed for two different glacier extents - 1969 (GI1) and 2012 (GI3). We applied the model to glaciers with an area $>100,000 \mathrm{~m}^{2}$. We only consider modelled depressions $>10,000 \mathrm{~m}^{2}$ following experiences of previous studies (Frey et al., 201ob; Linsbauer et al., 2016a; Linsbauer et al., 2012b)

\subsubsection{GLABTOP2}

The model GLAPTOP2 (Frey et al., 2014) quantifies ice thickness $h$ based on the shallow ice approximation (SIA):

$$
h=\frac{\tau}{f \rho g \sin a}
$$

where $\tau$ is the basal shear stress, $f$ is a shape factor, which accounts for which accounts for the lateral drag occurring at the sides of a glacial trough, thus correcting $h, \rho$ is the density of ice, $\mathrm{g}$ is gravitational acceleration and $\alpha$ is ice surface slope. Following the approach by Linsbauer et al. (2012a), this model utilizes an empirical relationship determined by Haeberli and Hölzle (1995) to solve equation (i). Ice thickness is calculated for random points on the ice surface. $\alpha$ is calculated within a moving window around the random cell. The moving window is scaled to meet an elevation criterion to avoid very low slopes which would lead to unrealistically thick ice in (i). Ice thickness at the random points is finally interpolated to the entire glacier surface. Ice thickness at glacier margin cells is set by the 
user. We reproduced the model in an own script, which allowed the modification of model parameters for testing.

The parameter $\tau$ (shear stress) is based on the formula

$$
\tau[k P a]=0.5+159,8 \Delta \mathrm{H}-43,5(\Delta \mathrm{H})^{2}
$$

for glaciers with $\Delta \mathrm{H}<1.6 \mathrm{~km}$. For glaciers with $\Delta \mathrm{H}>1.6 \mathrm{~km}$ a $\tau$ of $150[\mathrm{kPa}]$ is applied (Frey et al., 2014). For one glacier, $\tau$ is assumed to be constant. Consequently, most variables in (i) are constant, except the surface slope $\alpha$, which determines the shape of the bedrock topography, while $\tau$ scales glacier relief.

Table 2 Parameter of GLABTOP2 model (Frey et al., 2014) and tested variations.

\begin{tabular}{lll}
\hline PARAMETER & $\begin{array}{l}\text { DEFAULT- } \\
\text { VALUES }\end{array}$ & TESTED VALUES \\
\hline $\mathbf{f}$ & $0,8^{*}$ & $+/-0,1^{*}$ \\
tau $[\mathbf{k P a}]$ & $\begin{array}{l}\text { pro Gletscher } \\
\text { berechnet* }\end{array}$ & $+/-20 \% \%^{*}$ \\
hmin $[\mathbf{m}]$ & $50^{*}$ & $+/-25$ \\
hga [m] & 5 & +5 \\
Interpolation & IDW & TTR \\
$\mathbf{r}$ & $0,3^{*}$ & $+/-0,1$ \\
$\mathbf{n}$ & $3^{*}$ & \\
\hline
\end{tabular}

* According to (Frey et al., 2014)

Parameter testing was performed for $f$ (shape factor), $\tau$ (shear stress), $r$ (random cells / number of margin cells), hga (ice thickness of glacier margin cells), and the interpolation method (Inverse Distance Weighted IDW, TopoToRaster TTR) (Table 2). Model comparison and evaluation was performed by modelling on three different glacier extents (GI1, GI3, GI4) and using the mapped existing lakes from the Austrian Lake Inventory (Buckel et al. 2018) for validation. Best results with most lakes reproduced and best fit to lake area were delivered using values $f=0.9, \tau=\tau-0.2$ and IDW interpolation. With this combination, $\mathbf{2 1 . 2} \%$ of all lakes that evolved between GI1 and GI3 where modelled correctly based on the GI1 ice surface. For GI3 $17.2 \%\left(14.3 \%,>10,000 \mathrm{~m}^{2}\right)$ of lakes that evolved between $\mathrm{GI}_{3}$ and 2015 (GI4) could be reproduced by GLABTOP2. This parameter set was applied for the final modelling of potential glacier lakes for the Austrian Alps using GLABTOP2.

A total of 152 and 129 subglacial depressions $>10,000 \mathrm{~m}^{2}$ were modelled for the GI1 and GI3 glacier extents, respectively. These cover a total area of $8.6 \mathrm{~km}^{2}$ (GI1) and $5.8 \mathrm{~km}^{2}\left(\mathrm{GI}_{3}\right)$ and represent a storage capacity of $30 \mathrm{M}$ to $60 \mathrm{M} \mathrm{m}^{3}$ (Table 3 ). 
Table 3 Results of subglacial depressions modelling for the two time steps and both modelling approaches.

\begin{tabular}{llrrr} 
Modell & GI & \multicolumn{1}{c}{$\begin{array}{c}\text { Total } \\
\text { Number }\end{array}$} & $\begin{array}{l}\text { Total Area } \\
{\left[\mathbf{k m}^{\mathbf{2}} \mathbf{l}\right.}\end{array}$ & \multicolumn{2}{c}{$\begin{array}{l}\text { Total Volume } \\
{\left[\mathbf{m}^{\mathbf{3}} \mathbf{]}\right.}\end{array}$} \\
\hline GLABTOP2 & GI1 & 152 & 8.6 & $59,373,120$ \\
& GI3 & 129 & 5.8 & $30,999,700$ \\
HF & GI1 & 305 & 12.6 & $85,910,840$ \\
& GI3 & 190 & 7.4 & $45,880,732$
\end{tabular}

\subsubsection{Huss \& Farinotti model (HF)}

We used the approach of Huss and Farinotti (2012) for ice thickness modelling. The HF model was developed from the ice thickness estimation method presented by Farinotti et al. (2009). The HF model scored highest among the automated methods applicable at large scales compared within the Ice Thickness Models Intercomparison eXperiment (ITMIX, Farinotti et al. (2017), and has already been applied to all glaciers globally (Huss and Farinotti, 2012) and for regional glacier volume studies (e.g. Andreassen et al. (2015); Frey et al. (2014)).

The basic principle of the HF model is the estimation of ice volume flux along the glacier, from which local ice thickness is computed based on measured surface slope and the flow law for ice. The approach accounts for basal sliding conditions, variations in the valley shape, and the influence of ice temperature on ice flow using several adjustable parameters. The surface mass balance and the volumetric balance flux are calculated along a simplified longitudinal profile of the glacier for estimating the mean ice thickness of individual elevation bands. In a final step, elevation band thicknesses are extrapolated to all cells of a regular grid depending on local surface slope and the distance from the glacier margin. We refer the reader to Huss and Farinotti (2012) for more details on the model architecture.

The HF-model requires digitized glacier outlines and a digital elevation model as input. We ran the model for $10 \mathrm{~m}$ elevation bands from glacier outlines and glacier surface elevations on the basis of DEMs with $10 \mathrm{~m}$ resolution from the three Austrian Glacier Inventories, GI 1 (1969), GI 2( 1998) and GI 3 ( 2006). Parameters on valley shape factor, continentality and climate were kept as proposed in Huss and Farinotti (2012). Model validation and calibration was performed using a comprehensive data set of in-situ ice thickness measurements from 58 glaciers in the Austrian Alps (Fischer et al., 2015b). As an intermediate result, the apparent mass balance gradient, the primary model parameter accounting for the effects of surface mass balance distribution as well as ice flux, substantially decreases over time and has to be adjusted for each temporal increment to correctly reproduce observed ice thickness (cf. Helfricht et al., submitted). This reflects the general stagnation of glaciers in Austria. Relative errors in glacier mean modelled ice thickness against ice thickness measurements are between $3 \%$ and $8 \%$ for the different glacier inventories, with a maximum standard deviation of $16 \%$ considering the individual glaciers. Using the calibrated parameter set, $93 \%$ of the observed ice thickness change on a glacier-specific scale are captured for the periods between the glacier inventories. We applied optimized apparent mass balance gradients to all glaciers of the latest Austrian 
glacier inventory and found a volume of $16.4 \pm 3.5 \mathrm{~km}^{3}$ for the year 2006 . The ten largest glaciers account for $25 \%$ of area and more than $40 \%$ of total ice volume. An estimate based on mass balance measurements from nine glaciers indicates an additional volume loss of $3.5 \pm 0.4 \mathrm{~km}^{3}$ (i.e. $21.4 \pm 2.3 \%$ ) until 2016. Relative changes in area and volume were largest at glaciers smaller than $1 \mathrm{~km}^{2}$, and relative volume changes appear to be higher than relative area changes for all considered time periods.
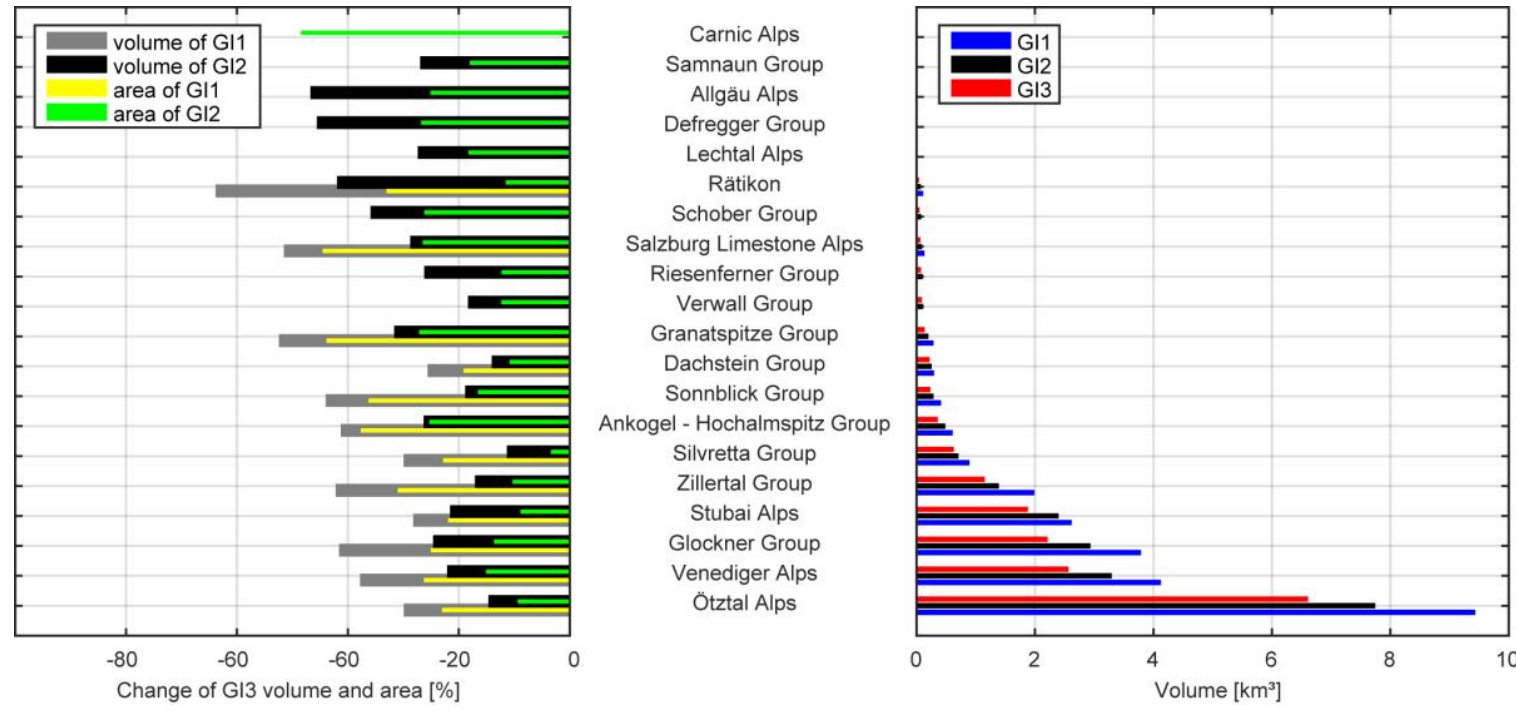

Figure 7 (A) Relative changes in volume and area from GI 1 and GI 2 to the latest glacier inventory (GI 3). (B) Total volume of all glaciers in the respective mountain ranges. The five smallest volumes are less than $0.01 \mathrm{~km}^{3}$. Regions are ordered according to increasing ice volume (from Helfricht et al., submitted)

The HF model delivers 305 depressions within the GI1 extent and 190 locations within GI3 for all objects $>10,000 \mathrm{~m}^{2}$ (Table 3 ). Representing an area of 12.6 (GI1) and $7.4 \mathrm{~km}^{2}\left(\mathrm{GI}_{3}\right)$ a potential total volume between $45 \mathrm{M}$ and $85 \mathrm{M} \mathrm{m}^{3}$ of water and sediments could be stored in these depressions.

\subsubsection{Potential new lakes underneath the current glacier extent}

Currently, approximately $330 \mathrm{~km}^{2}$ of Austria is covered by about 360 glaciers $>100,000 \mathrm{~m}^{2}$ and numerous smaller ice patches (according to GI4 Buckel and Otto, 2018). Our modelling results show that, within this area, between 102 and 227 potential depressions can be expected (Table 4,) summing up to a total area between 5.1 and $10.4 \mathrm{~km}^{2}$, according to the different model types and runs. These potential depressions account for a storage capacity between $25 \mathrm{M}$ and $70 \mathrm{M} \mathrm{m} \mathrm{m}^{3}$ in the uppermost mountain regions. Mean depth of these potential lake locations is between 5 and $7 \mathrm{~m}$ and maximum lake depths between 60 and $270 \mathrm{~m}$. The two deepest depressions generated by the models are located underneath the glaciers "Übergossene Alm" (GLABTOP2) and "Obersulzbachkees" (HF), both located in Salzburg. Both locations area characterized by a very low surface inclination $<3^{\circ}$. However, we regard this extreme depth of $270 \mathrm{~m}$ for the "Übergossene Alm" glacier as modelling artefact since the other runs for this glacier (GLABTOP2 $\mathrm{GI}_{3}$, HF GI1 and $\mathrm{GI}_{3}$ ) produce a depressions with significantly less depth between 10 and $20 \mathrm{~m}$ at maximum. At Obersulzbachkees, the same depressions is also represented in all models, but depths differ between 30 and $100 \mathrm{~m}$ for GLABTOP2 and HF models, respectively. These results highlight 
distinct differences between GLABTOP2 and the HF-model. GLABTOP2 generates a lower number of lakes with a higher mean size but lower total area and lower total volume compared to the HF-model (Table 4). Accordingly, the HF-model produces more and generally deeper depressions. Figure 8 depicts the modelling outcomes for the Großglockner area. In this case, depressions modelled by GLABTOP2 are often larger in size, compared to several small depressions at the same locations produced by HF. This can be observed at the Pasterze glacier plateau or the Bockkarkees, south of the Großer Bärenkopf peak. In case of the Pasterze glacier tongue, the results are reversed with larger depressions predicted by the HF-model compared to several smaller features derived by GLABTOP 2 (Figure 8).

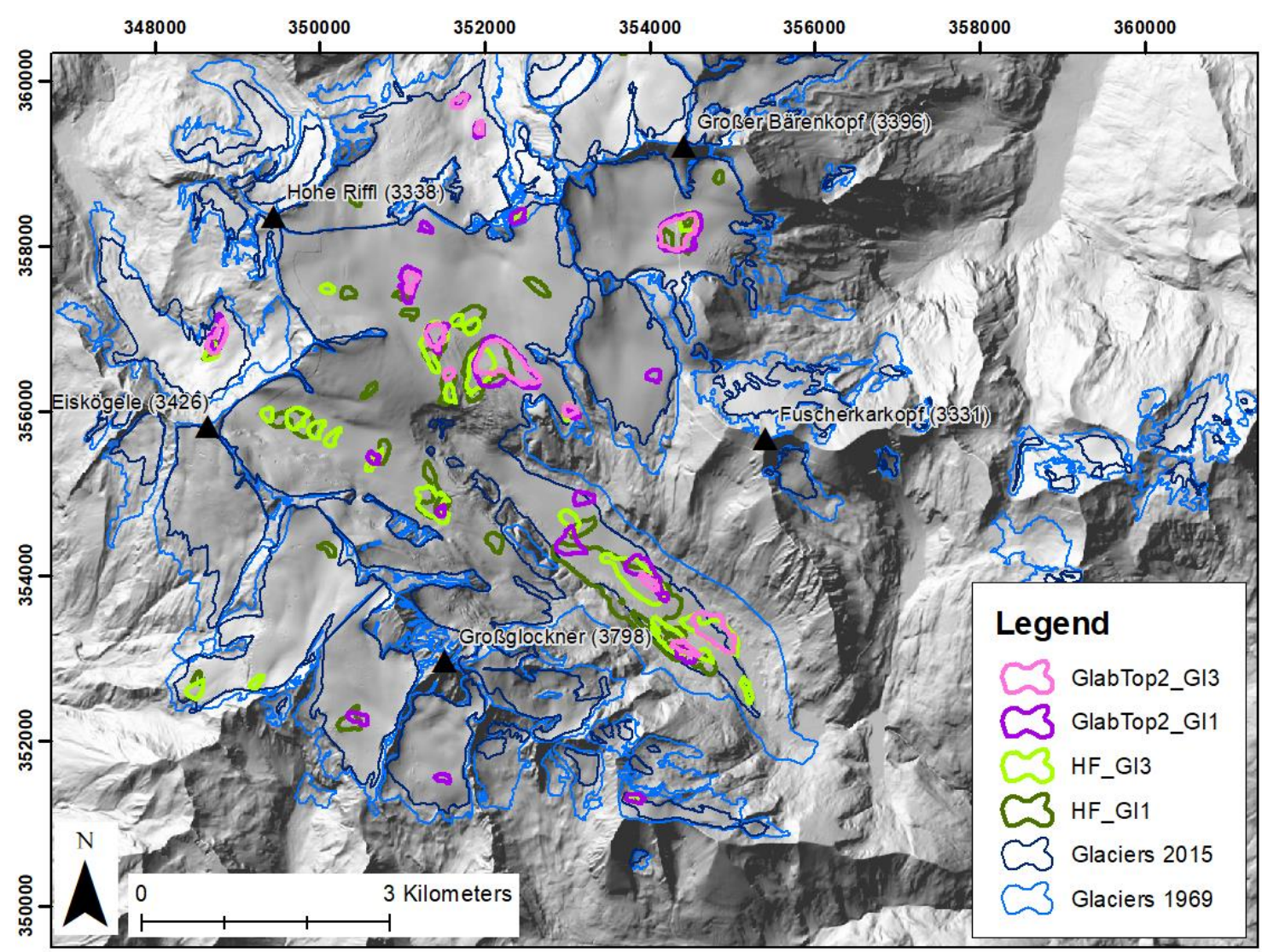

Figure 8 Modelled subglacial depressions for the Großglockner area with Pasterze glacier in the center. Depressions have been clipped to the current (2015) glacier extent. 
Table 4 Total number of potential new lakes in Austria within glacier area of 2015 (GI4).

\begin{tabular}{|c|c|c|c|c|c|c|c|}
\hline Model & $\mathbf{G I}^{*}$ & $\begin{array}{l}\text { Total } \\
\text { No }\end{array}$ & $\begin{array}{l}\text { Mean } \\
\text { Size }\left[\mathrm{m}^{2}\right]\end{array}$ & $\begin{array}{l}\text { Total Area } \\
{\left[\mathbf{k m}^{2}\right]}\end{array}$ & $\begin{array}{l}\text { Total } \\
\text { Volume } \\
{\left[\mathrm{m}^{3}\right]}\end{array}$ & $\begin{array}{l}\text { Mean } \\
\text { Depth [m] }\end{array}$ & $\begin{array}{l}\text { Max } \\
\text { Depth [m] }\end{array}$ \\
\hline \multirow[t]{2}{*}{ GLABTOP2 } & GI1 & 128 & 59,234 & 7.5 & $52,239,980$ & 6.89 & 270 \\
\hline & GI3 & 102 & 49,646 & 5.1 & $25,066,305$ & 4.95 & 60 \\
\hline \multirow[t]{2}{*}{ HF } & GI1 & 227 & 46,062 & 10.4 & $70,683,277$ & 6.76 & 110 \\
\hline & GI3 & 162 & 40,733 & 6.6 & $40,186,479$ & 6.09 & 90 \\
\hline
\end{tabular}

\subsection{Model evaluation and validation}

\subsubsection{Comparison with existing lakes}

We evaluated the model quality using the existing lakes mapped in the Austrian lake inventory (Buckel et al., 2018). Number, location, and size of the modelled subglacial depressions from the Gl1 model run were compared to existing lakes, which evolved within the ice-free space between GI1 (1969) and GI4 (2015). This comparison faces some problems due to the nature of the modelling approach that only delivers bedrock-dammed lakes. Therefore, only lakes classified as bedrock-dammed and embedded-in-glacial-sediment were considered for this comparison. The later type is chosen assuming that it represents locations where bedrock depressions have been partially covered with debris, masking the bedrock dam. A buffer of $100 \mathrm{~m}$ was applied for the selection of the lakes, and we intersected the modelled depressions $>10.000 \mathrm{~m}^{2}$ with all lakes of the above type. Consequently, modelled depressions may also intersect with lakes $<10.000 \mathrm{~m}^{2}$.

Table 5 Comparison of existing lakes and modelled lakes.

\begin{tabular}{|c|c|c|c|c|c|}
\hline \multirow{2}{*}{$\begin{array}{l}\text { Time } \\
\text { period }\end{array}$} & \multirow{2}{*}{$\begin{array}{l}\text { Existing lakes } \\
\text { (bedrock-dammed, } \\
\text { embedded) }\end{array}$} & \multicolumn{2}{|c|}{ Modelled lakes ${ }^{\infty}$} & \multicolumn{2}{|c|}{ Overlap (\%) } \\
\hline & & GLABTOP2 & HF & GLAPTOP2 & HF \\
\hline $1969-2008$ & $60\left(83^{*}\right)$ & 6 & 21 & $10 \%$ & $35 \%$ \\
\hline $2008-2015$ & $45\left(59^{\star}\right)$ & $7\left(18^{x}\right)$ & $10\left(14^{x}\right)$ & $16 \%\left(40 \%^{x}\right)$ & $22 \%\left(31 \%^{x}\right)$ \\
\hline
\end{tabular}

* total no. of lakes

${ }^{\infty}$ depressions $>10.000 \mathrm{~m}^{2}$

${ }^{x}$ using GI3 as input DEM

This comparison reveals that between 10 and $40 \%$ of depressions are modelled at positions of existing lakes (Table 5 ). Around $20-35 \%$ of the existing lakes where reproduced by the HF model, while GLAPTOP2 produces between 10 and $16 \%$. Using the GI3 glacier surface as input data, this number changes to $40 \%$ and $31 \%$ for the period 2008-2015 for GLABTOP2 and HF, respectively. Figure 9 shows the performance of the models in relation to existing lakes in the Großvenediger range. While the proglacial lake in the Obersulzbach valley (red circle on the top right) is reproduced to a certain extent by all models, the lake in the neighboring Krimmler valley (red circle on the left) is not predicted by any of the models. 
One reason for this missing lake is that lake formation started already before GI1, with the effect that probably parts of the lake have been present in the DHM used for modelling GI depressions. This shows that the prediction of lakes at the glacier front is strongly affected by the input data and the existing steepness. In this case the glacier tongue most probably retreated to a great extent from the flat area thus preventing the generation of a depressions by the models. However, despite the relatively good agreement for the HF model, most lakes are not predicted. Moreover, even if the models predict the general locations of the potential lakes correctly, the shape and size of the modelling result and the real lakes differ in most cases (cf. lake Sulzsee at Obersulzbachkees in Figure 9).

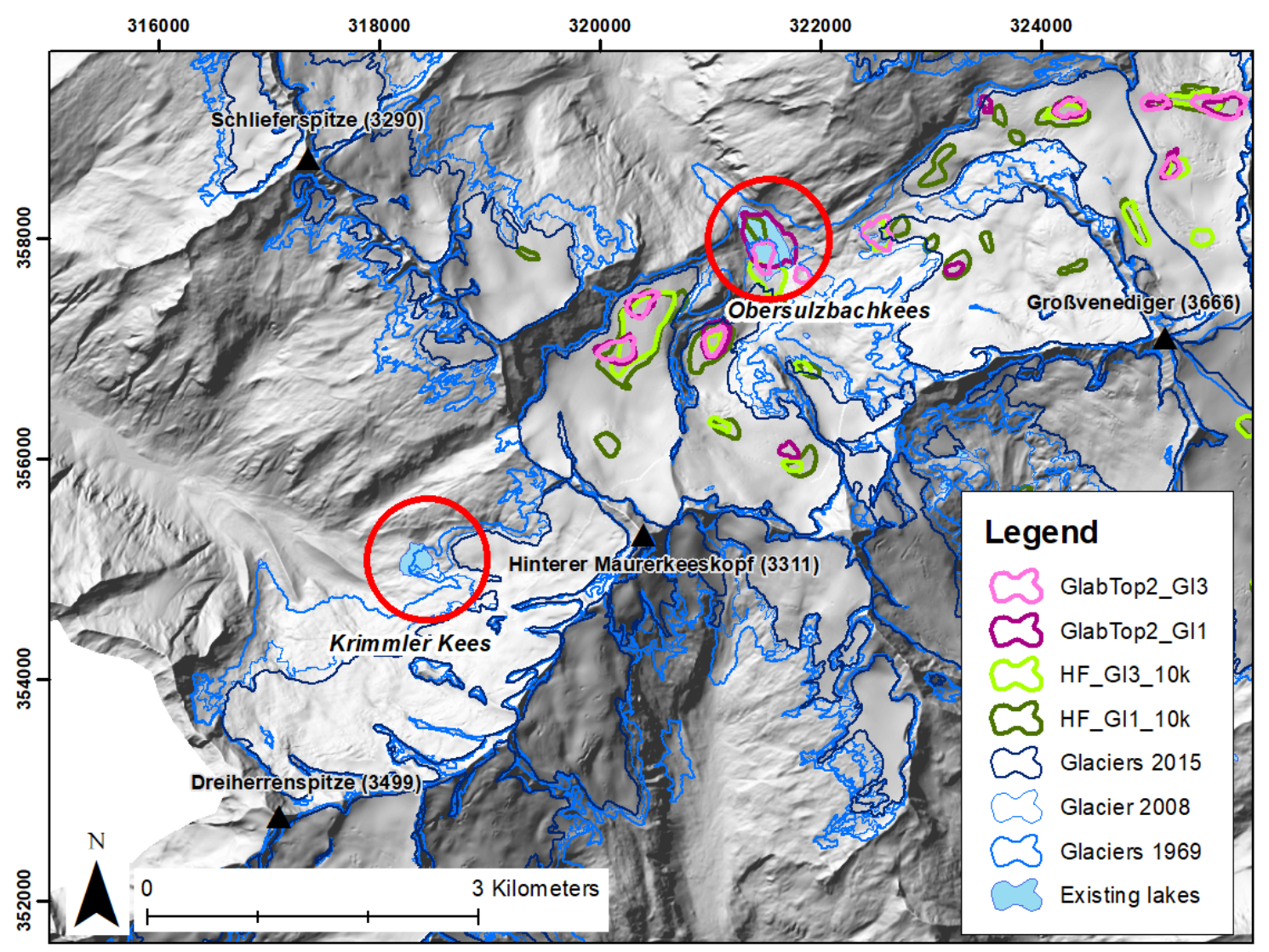

Figure 9 Modelling results for the Großvenediger range. While the proglacial lake in the Obersulzbach valley (red circle on the top right) is reproduced to a certain extent by all models, the lake in the neighboring Krimmler valley (red circle on the left) is not predicted by any tested modelling approach. 


\subsubsection{Model results versus field data}

Performance of ice thickness models can be evaluated using existing field data on glacier thickness based on geophysical measurements. In the field, ice thickness is predominantly determined using ground-penetrating radar (GPR), but refraction seismic has also been applied on glaciers (Brückl, 1980). A crucial control on the quality and resolution of GPR data is the choice of antenna frequency and the density of measurements on the glacier. Very low frequencies and large measurement intervals may result in low-resolution and accuracy images of the bedrock interface. We therefore collected the most valuable existing data sets to validate the ice thickness models, as well as the derived subglacial topography at highest resolution possible. In Austria a large dataset exists on ice thickness derived from low-frequency GPR (3-6 MHz) for 66 Austrian glaciers (Fischer et al., 2015b). Most of these data was collected using a large measurement spacing of up to $100 \mathrm{~m}$. Consequently, the bedrock topography may not be represented well enough to identify bedrock depressions using these data. The dataset by Fischer et al. (2015b) does not include information on glacier surface height. Thus, it cannot be used to determine the topography of the glacier bed and compare potential bedrock depressions locations. High-resolution GPR data exists only for a handful of glaciers including the Schmidingerkees, Wurtenkees, Fleißkees, Goldbergkess, and Ödenwinkelkees.

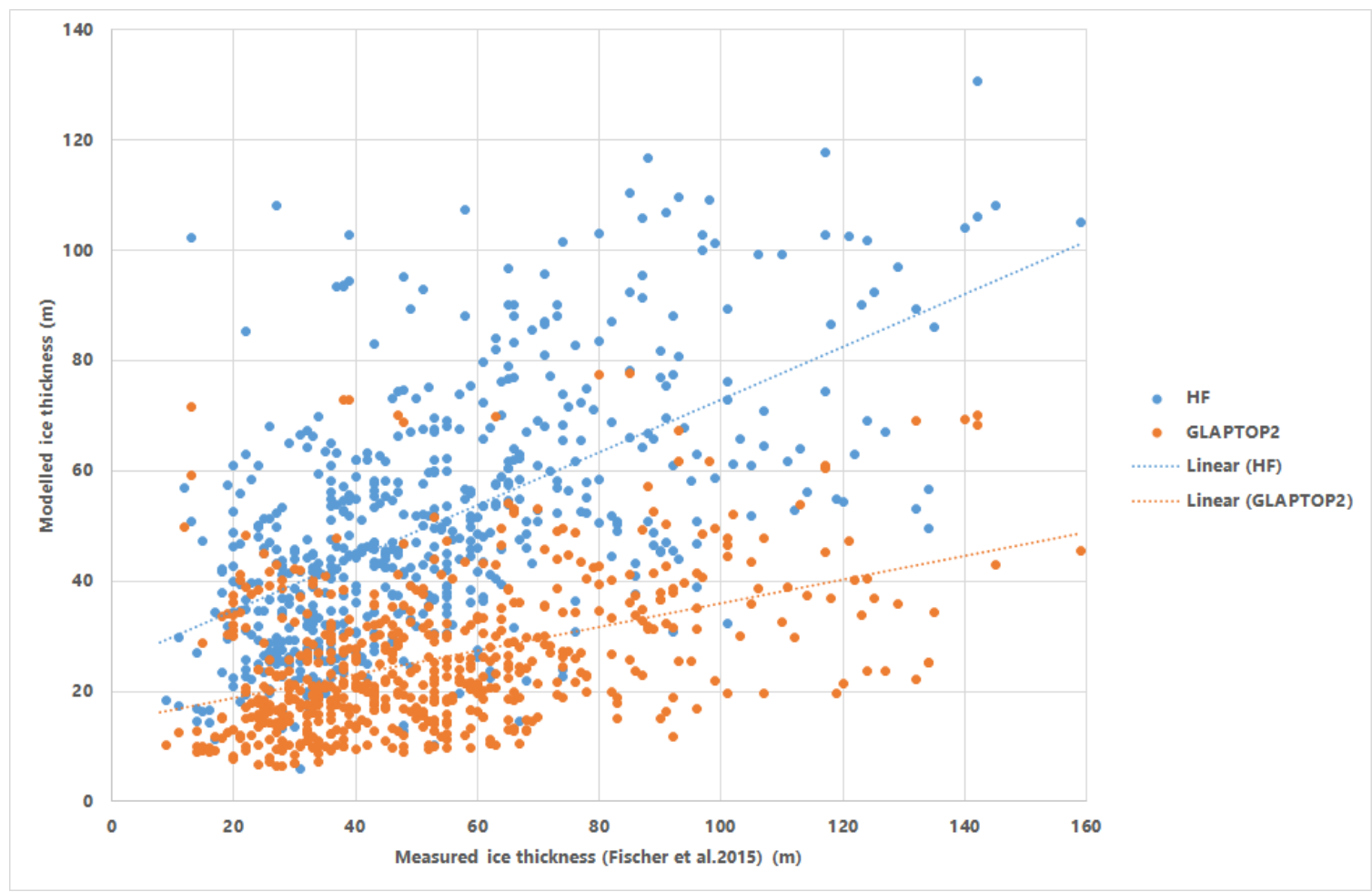

Figure 1o Comparing modelled ice thickness values with measured values collected by lowfrequency GPR for a selected number of glaciers (6oo measurement on 16 glaciers, data from Fischer et al. (2015b)). 
Comparing the modelled ice thickness values on a point-to-point basis with the lowfrequency GPR data on ice thickness reveals a very high divergence between the models and the field data (Figure 10). Modelled values are significantly lower with a large standard deviation, with GLABTOP2 portraying a mean difference of $-24 \mathrm{~m}$ (STD $24 \mathrm{~m}$ ), and HF producing mean differences of $-3 \mathrm{~m}$ (STD $22 \mathrm{~m}$ ) compared to the measured values.

In order to assess the quality of the modelled subglacial topography, which is essential for evaluating the modelled depressions and hence future lakes, we compared high resolution GPR data including glacier surface heights with the subglacial topography generated by the models. Comparing measured and modelled glacier beds at six GPR lines on three glaciers shows highly variable results (Figure 11, 12). The altitude of the modelled and measured bedrock surfaces differs in most cases. In all examples, GLABTOP2 (orange lines) bedrock surfaces are much higher than HF (green line) and the GPR (grey line) surfaces. Moreover, also the topography is not well represented in all lines, with consequences on the potential identification of depressions. Even though the examples are linear profiles only, they allow identifying potential pitfalls when deriving bedrock depressions from the modelling data. The measured GPR data show potential depressions at the Schmidingerkees (Figure $11 \mathrm{~B}, \mathrm{x}=$ 400-500 $\mathrm{m}$ ) and the Kleinfleisskees (Figure 12A, $\mathrm{x}=150-200 \mathrm{~m}$ ). Both locations are not reproduced by the models. At Kleinfleisskees, HF would probably have generated a small depressions (Figure 12A, orange line, $\mathrm{x}=160-175 \mathrm{~m}$ ). In contrast, the examples also depict potential depressions in the model, which are not present in the GPR data (Figure $11 \mathrm{~B}$, orange line, $\mathrm{x}=\mathbf{1 2 0}-\mathbf{2 5 0} \mathrm{m}$; Figure $12 \mathrm{C}$, orange line, $\mathrm{x}=10-130 \mathrm{~m}$ ).

These comparisons show that ice thickness values and bedrock topography deviated strongly between modelling and field data. This may explain the low number of reproduced lakes especially by the GLABTOP2 approach. 
Otto et al. (2019): Futurelakes - Final Report

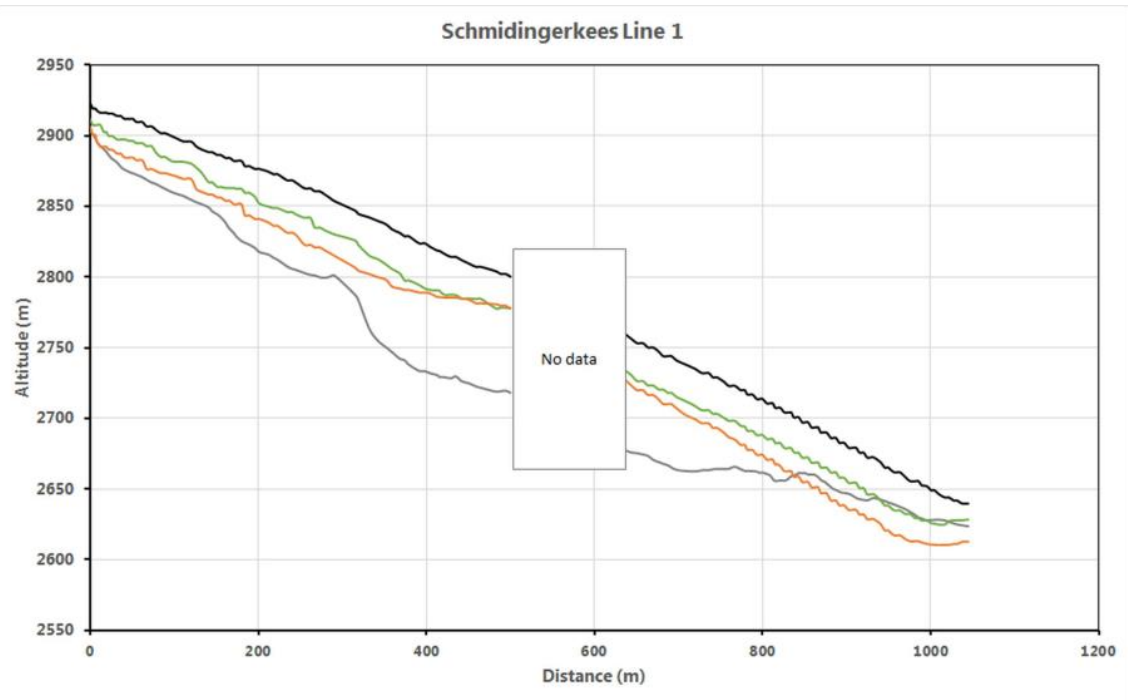

- Glacier surface -Bedrock GPR -Bedrock GL2 - Bedrock HF

Schmidingerkees Line 2

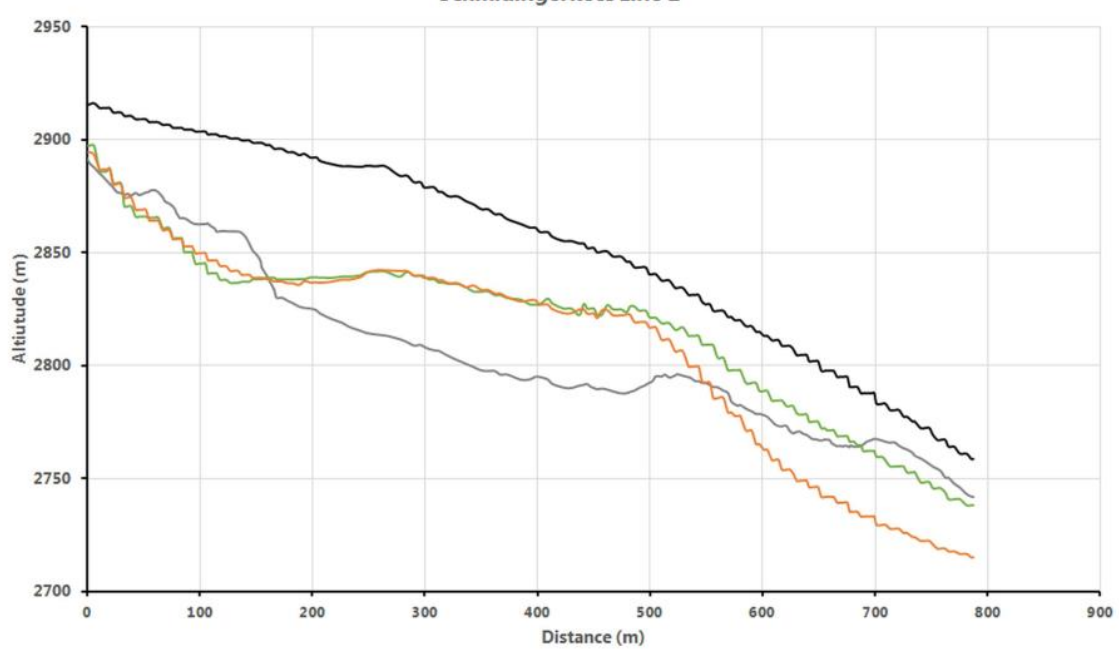

B

— Glacier Surface

- Bedrock GPR — Bedrock GL2 - Bedrock HF

Schmidingerkees Line 3

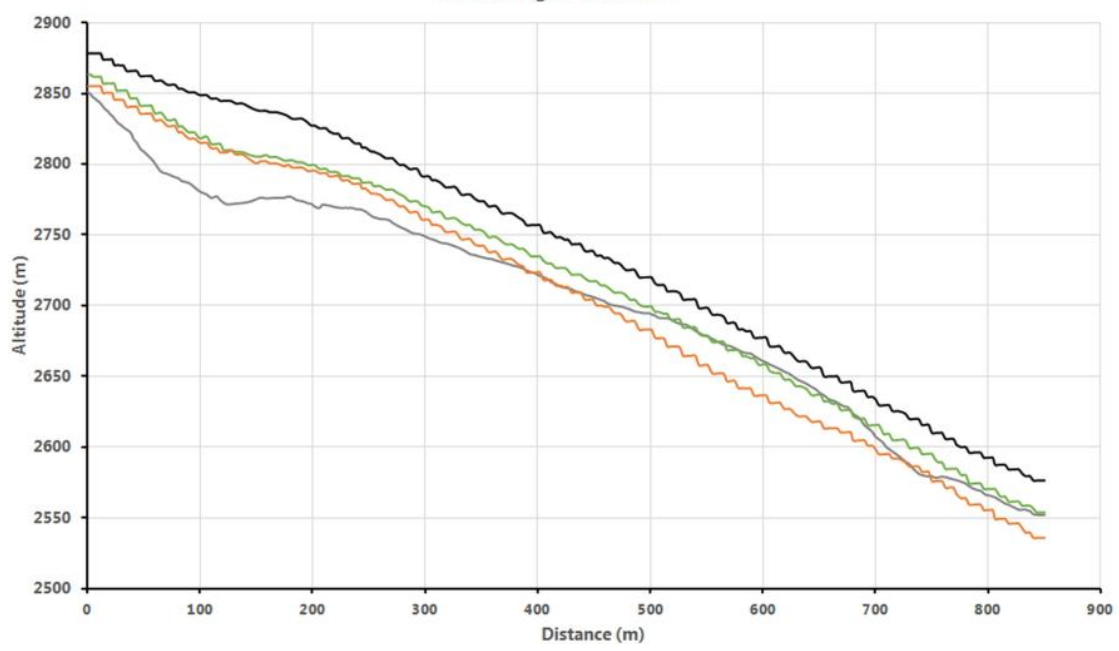

C

— Glacier Surface —Bedrock GPR —Bedrock GL2 — Bedrock HF

Figure 11 Longitudinal profiles of GPR measurements at Schmidingerkees. 
Otto et al. (2019): Futurelakes - Final Report
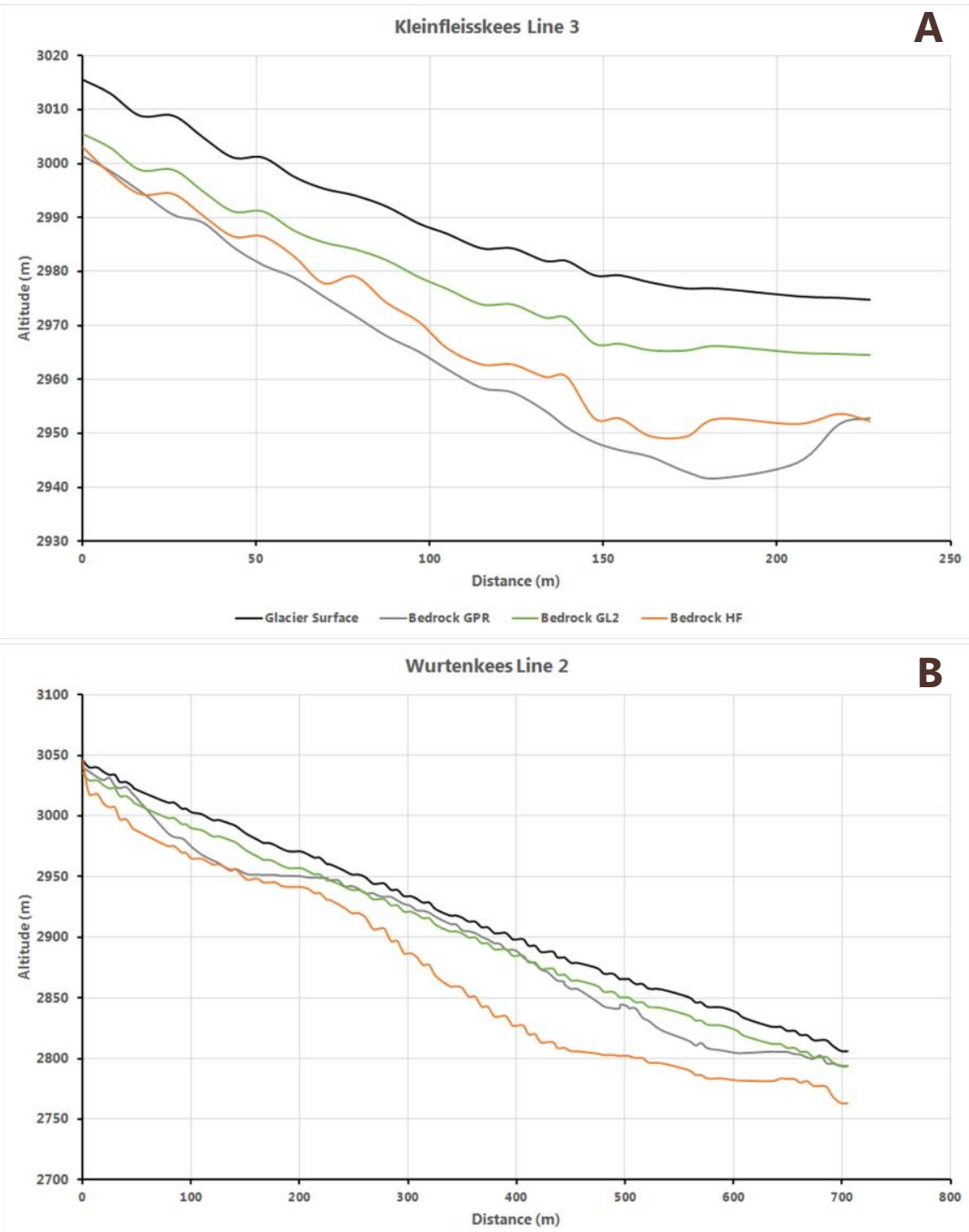

- Glacier Surface - Bedrock GPR — Bedrock GL2 - Bedrock HF

Wurtenkees Line 3

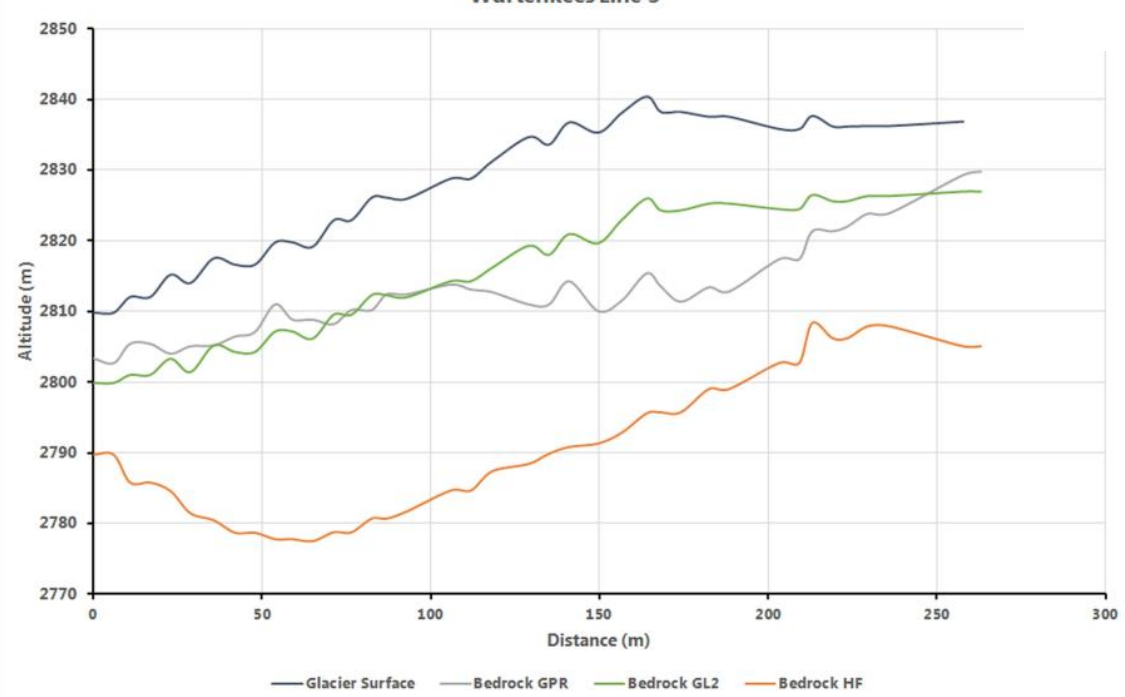

Figure 12 Longitudinal profiles of GPR measurements at $(A)$ Kleinfleisskees and $(B, C)$ Wurtenkees. 
We also tested the GLABTOP2 results on ice thickness in relation to field data. Figure 13 plots calculated slope values, derived from the GLABTOP2 model, against measured ice thickness values derived from GPR for four different glaciers. All glaciers show a similar deviation between modelled and measured ratios. For steeper slopes GLABTOP2 delivers realistic ice thickness values, whereas for lower slopes, like plateau areas or glacier tongues, ice thickness is significantly lower compared to field data (Figure 13, A-D).

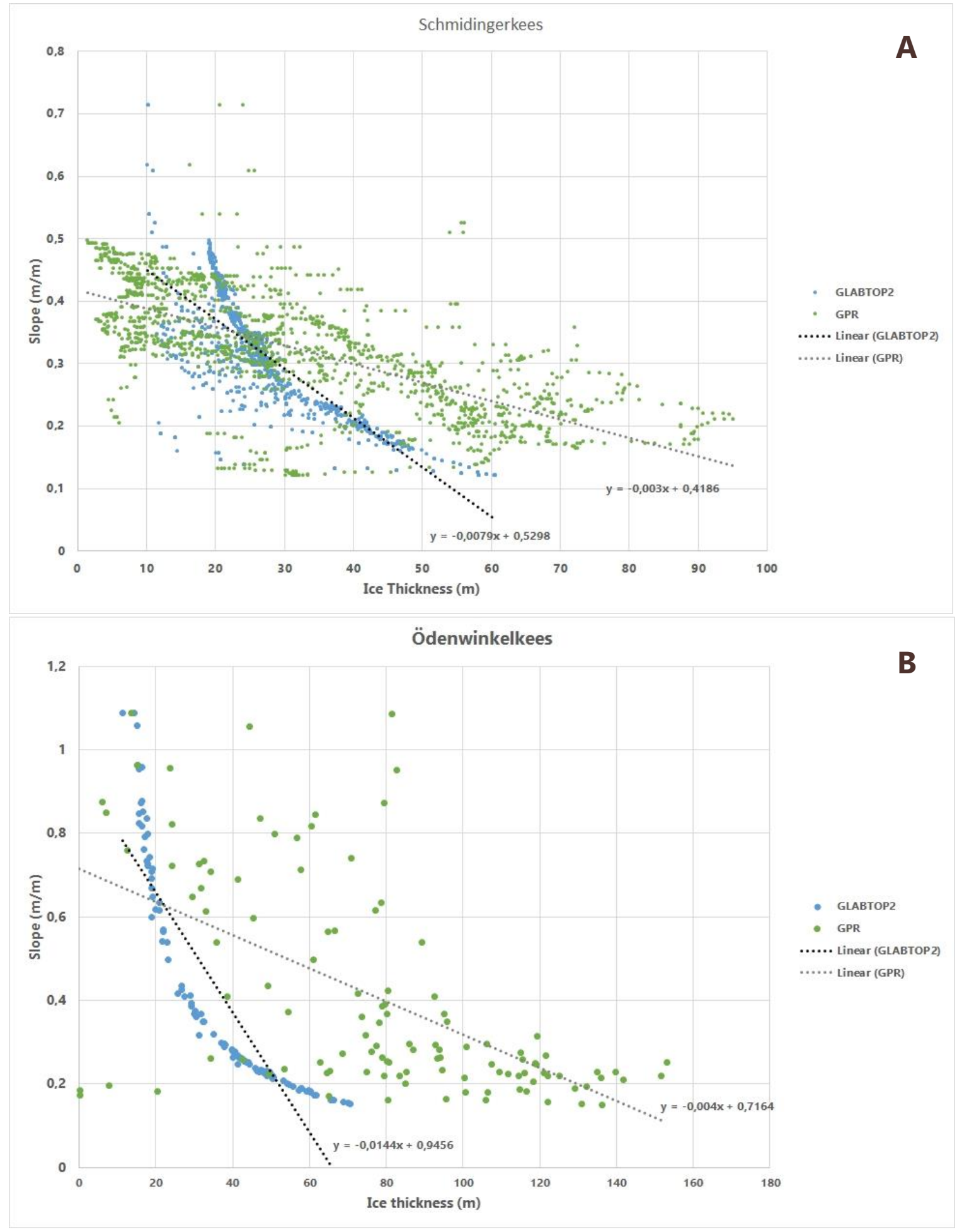


Otto et al. (2019): Futurelakes - Final Report

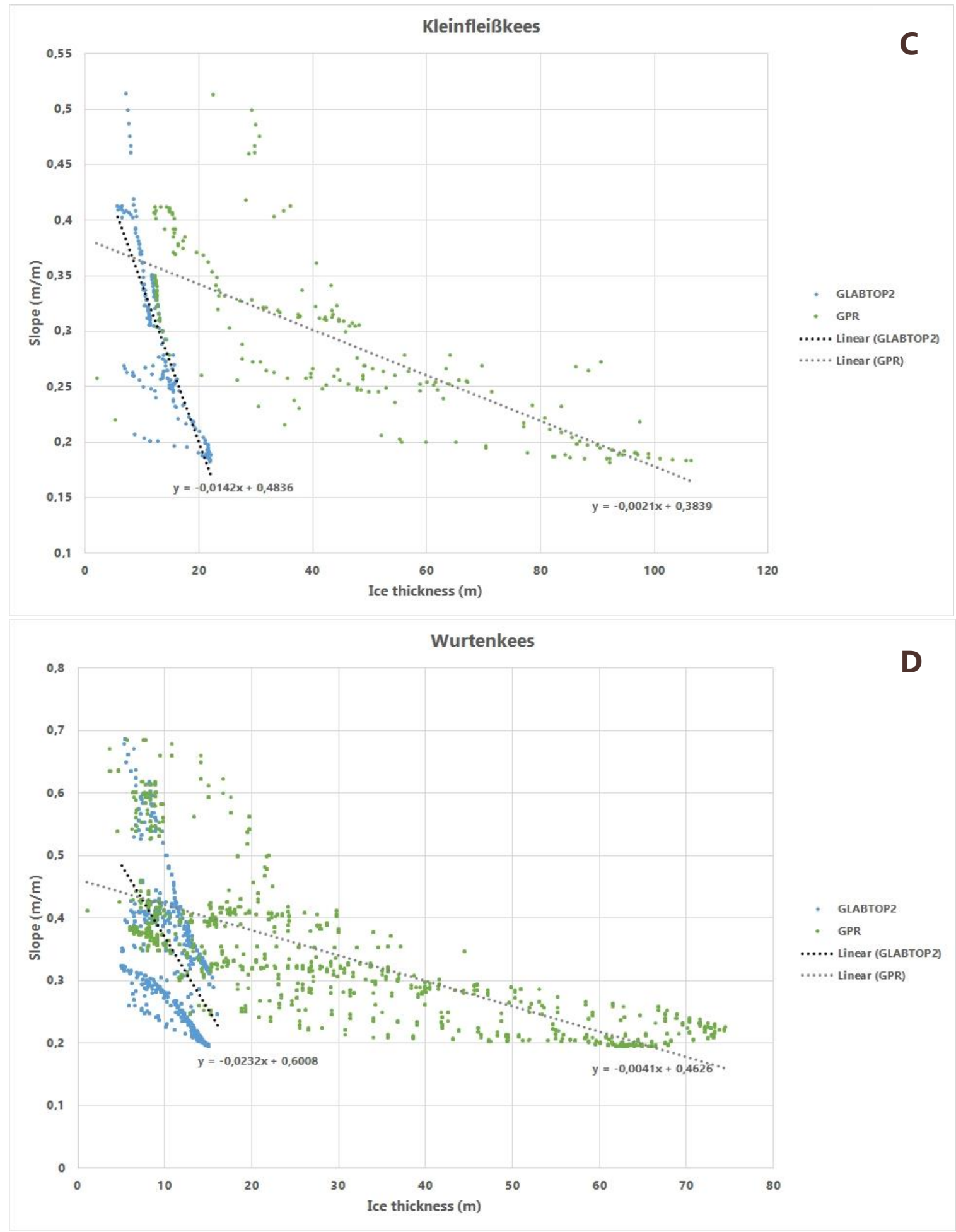

Figure 13 Comparing slope-thickness relationships between field (GPR) and model data (GLABTOP2) for Schmidingerkees (A), Ödenwinkelkees (B), Kleinfleisskees (C) and Wurtenkees (D). Slope value is extracted from the GLABTOP2 model. 


\subsubsection{An alternative approach to estimate potential new lakes}

In order to evaluate the modelled total lake area we quantified the ratio of emerged lake area per year and area released by the melting glaciers per year (Table 6). The area of new lakes emerged per year since the LIA shows little variation between the different periods of glacier retreat with a lower ratio between 1998 and 2006. This is related to a stronger increase of ice free area compared to new lake area. We applied the median of this ratio to estimate the total new lake area within the potential future release area. To estimate the potential increase in released area by glacier melt we applied two estimations. First we used the latest observed trend in increase of the ice-free area between 2006 and 2015. In this period approximately $9.7 \mathrm{~km}^{2}$ per year of terrain was exposed due to glacier retreat. Considering this trend continues, the entire amount of glaciers in Austria will be gone before 2050 (Figure 14). Applying the lake release area ratio to this trend results in a yearly emergence of $68,000 \mathrm{~m}^{2}$ of lakes and in a total lake area of $2.4 \mathrm{~km}^{2}$ until 2050. Combined with the total lake area that has formed since the LIA this sums up to $5.3 \mathrm{~km}^{2}$ of glacial lakes. Assuming a similar mean lake size of $12,000 \mathrm{~m}^{2}$, which formed on average between 2006 and 2015, we would have to expect another 200 lakes within the remaining glacier area of 2015 .

Table 6 Ratio between emerged lake area per year and area released by glacier melt per year (data from Buckel et al. (2018); Fischer et al. (2015a)).

\begin{tabular}{lc} 
Period & Lake area / year : ice-free area / year \\
\hline $1850-1969$ & 0.0072 \\
$1969-1998$ & 0.0069 \\
$1998-2006$ & 0.0054 \\
$2006-2015$ & 0.0081
\end{tabular}

In a different approach we applied scenarios of glacier decrease taken from Zekollari et al. (2018). They modelled the future evolution of glaciers in the European Alps for three climate scenarios (RCP 2.6, RCP 4.5, RCP 8.5) based on glacier changes between 2008 and 2017 using a modified ice-thickness model evolved from the HF approach. For the entire Alps their models produce a reduction of total glacier area of about $45 \%$ from 2017 until 2050 (RCP $2.6: 43.9 \%$, RCP 4.5: 45.6\%, RCP 8.5:48.8\%). For 2100 the models predicts a reduction to $62.1 \%,-74.9 \%$, and $-91.1 \%$ for RCP 2.6, RCP 4.5 , and RCP 8.5, respectively. We applied these values to the glacier area of 2015 , which results in an increase in ice-free terrain to $760 \mathrm{~km}^{2}$ für 2050 and $816.8 \mathrm{~km}^{2}$ (RCP 2.6), $858.7 \mathrm{~km}^{2}$ (RCP 4.5), and $911.5 \mathrm{~km}^{2}$ (RCP8.5) for 2100 (Table 7 ). This projected trend of glacier melt however represents a decrease of glacier melt compared to the most recent trends and thus a slow down in emergence of ice-free area (Figure 14). The authors also acknowledge this discrepancy to measured data and relate this to stagnant ablation areas and disconnected ice patches that are included in glacier inventories, but cannot be reproduced in their models (Zekollari et al., 2018). The resulting difference would preserve glaciers in the Austrian Alps until the late $21^{\text {st }}$ century (Table 6). 
Applying the same ratio of lake emergence to these potential scenarios results in a total lake area of almost $4 \mathrm{~km}^{2}$ in 2050 and values between 4.3 and $5.0 \mathrm{~km}^{2}$ until 2100 . This would relate to another 200-265 new lakes between 2015 and 2100.

To conclude, these simple approximations predict the emergence of substantially less lake area than the models. The number of potential new lakes is slightly higher compared to the models, which is related to the lower mean lake area of $12,000 \mathrm{~m}^{2}$ compared to around $50,000 \mathrm{~m}^{2}$ generated by the models (Table 4 ).

Table 7 Potential future cumulative release area by glacier melt and potential total cumulative new lake area based on the extrapolation approach described.

\begin{tabular}{|c|c|c|c|c|c|c|c|c|}
\hline \multirow[t]{2}{*}{ Year } & \multicolumn{3}{|c|}{ Total ice-free area $\left[\mathrm{km}^{2}\right]$} & \multicolumn{5}{|c|}{ Total lake area $\left[\mathrm{km}^{2}\right]$} \\
\hline & $\begin{array}{l}\text { Linear } \\
\text { increase }\end{array}$ & RCP 2.6 & RCP 4.5 & $\begin{array}{l}\text { RCP } \\
8.5\end{array}$ & $\begin{array}{l}\text { Linear } \\
\text { increase }\end{array}$ & $\begin{array}{l}\text { RCP } \\
2.6\end{array}$ & $\begin{array}{l}\mathrm{RCP} \\
4.5\end{array}$ & $\begin{array}{l}\text { RCP } \\
8.5\end{array}$ \\
\hline 2015 & 613,00 & 613,00 & 613,00 & 613,00 & 2,94 & 2,94 & 2,94 & 2,94 \\
\hline 2050 & 951,33 & 760,60 & 760,60 & 760,60 & 5,34 & 3,98 & 3,98 & 3,98 \\
\hline 2100 & - & 816,69 & 858,67 & 911,48 & - & 4,38 & 4,68 & 5,05 \\
\hline
\end{tabular}

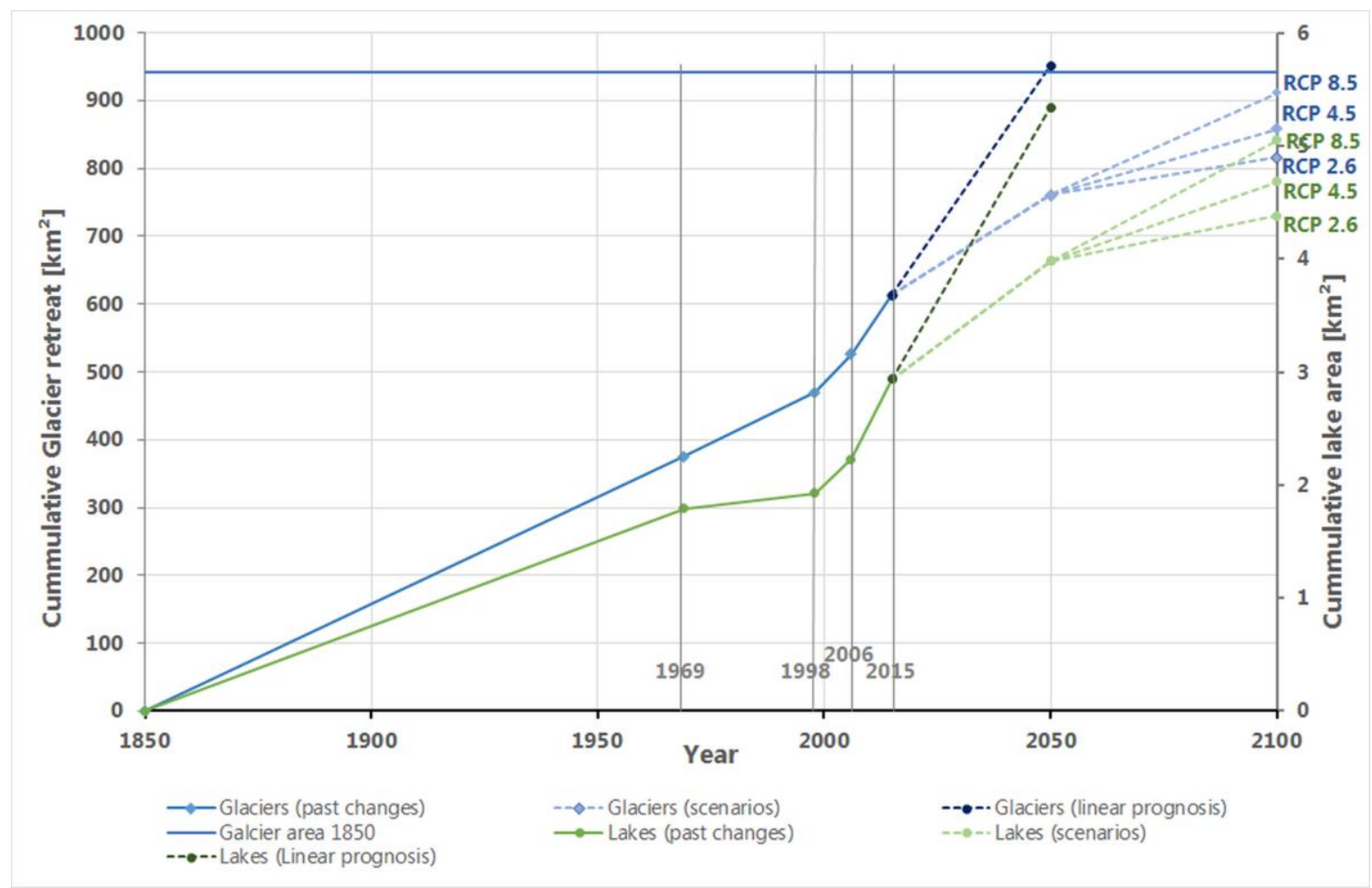

Figure 14 Plotting trends of emerging lake area with glacier retreat. The linear prognosis refers to a continuation of glacier retreat applying the mean melt rate between 2006 and 2015. Other scenarios of glacier melt are taken from Zekollari et al. (2018). 


\subsection{Discussion}

Our analysis shows significant uncertainties in predicting potential future lakes, which need to be considered when evaluating the general applicability and the predictive capacity of the approach. Uncertainties can be attributed to the assumptions and simplifications of the ice thickness models such as GLABTOP2 and HF for the detection of subglacial depressions.

Ice thickness models are designed for quantifying the total ice volume of a glacier or an entire region. These data are used to assess water quantities stored in glaciers and utilized for example for assessing the contribution of glaciers to global sea level rise. The models have been developed because data on ice thickness are scarce and tedious to acquire. An extensive model comparison by Farinotti et al. (2017) revealed deviations between model and measured ice thickness on the order of $10 \pm 24 \%$ of the mean ice thickness. However, mean ice thickness is not relevant for our task, since we want to create subglacial topography from the modelled ice body. Differences between the models applied here are quite large, especially when comparing the measured subglacial topography at individual sites instead of mean ice thickness values (2.3.2). Here, the performance of our models is highly diverse and often poor for different types and settings of glaciers. One source of uncertainty in this regard may be the generalization of locally calculated ice thickness values (at random points in GLABTOP2, on a longitudinal profile in HF) to the entire glacier area. To perform this generalization, additional parameterization of the models is necessary (interpolation technique, treatment of glacier edges, size of elevation bins, procedure of surface slope averaging, etc.), which need to be optimized and can be an additional source of error.

Our results show a distinct and heterogeneous deviation between modelled and measured ice thickness (Figure 10). We also conclude that for the validation and interpretation of the subglacial topography, high-resolution data is necessary. This includes detailed modelled topographies as well as high-resolution GPR data. Interpolation of modelling results may lead to less detailed subglacial topography, depending on the initial source data density (in case of GLABTOP 2 these are the number of random points) and the type of interpolation method. High-resolution GPR data on glaciers are derived by antenna frequencies of 50-100 $\mathrm{MHz}$ or higher, and trace distances below $5 \mathrm{~m}$. GPR data of lower frequency may result in topographic information that mask subglacial depressions, due to a large radar footprint (i.e. the area over which the radar signal is horizontally averaged at depth due to beam widening: e.g. $100 \mathrm{MHz}$ antenna at $50 \mathrm{~m}$ depth: footprint diameter: 6-12 m, $4 \mathrm{MHz}$ antenna at $50 \mathrm{~m}$ depth: footprint $30-60 \mathrm{~m}$.).

On the other hand, while detailed GPR measurements can be an advantage, a detailed DEM of the ice surface may contain additional information on surface hydrology and other surface processes, rather than ice flow.

GLABTOP2 is based on the shallow ice approximation (see equation i) and thus assumes that ice flow can be modelled only from the gravitational driving stress and the basal drag. Consequently, the only variables required to find $h$ in equation (i) are the basal shear stress $\tau$ and the ice surface slope $\alpha$. While this is already a considerable simplification of the full stokes solution, GLABTOP 2 uses a very simple empirical relationship to calculate a single $\tau$ 
per glacier from the glacier elevation range $\Delta H$ (equation ii) (Haeberli and Hölzle, 1995). This formula was derived from data by Maisch and Haeberli (1982) who reconstructed lateglacial ice extents for 63 glaciers in the Swiss Alps. Geometric parameters of the reconstructed glacier extent have been mapped from topographic maps including $\Delta \mathrm{H}$, length, and mean ice thickness. Maisch and Haeberli (1982) also used equation (i) for the calculation of $\tau$ from the estimated mean ice thickness of their reconstructed glaciers. This represents a significant simplification of the parameter $\tau$, which is supposed to be highly variable within the glacier area. For the Schmidingerkees, for example, a glacier with $\Delta \mathrm{H}=480 \mathrm{~m}$, GLABOPT2 uses a value of $67 \mathrm{kPa}$, while $\tau$ calculated from measured ice thickness values ranges between 4 and $148 \mathrm{kPa}$ with a mean value of $42 \mathrm{kPa}$. Thus, using a mean value for shear stress based on the empirical relationship by Haeberli and Hölzle (1995) carries a high potential of missing crucial aspects of ice dynamics that are critically needed to adequately reconstruct ice thickness and generate a model of the glacier-bedrock interface. As we showed, the applied mean shear stress reproduces realistic values in steeper areas compared to low inclined zones of the glacier (Figure 13). This has implications on the potential location of overdeepenings, since according to the morphological criteria mentioned above, as well as the SIA, subglacial depressions tend to form beneath areas of flat glacier surfaces.

It also has to be considered, that crucial parameters for ice flow change with the actual balance states of the glaciers. The calibration set-up for the HF-method revealed that a reduction of ice flux over the last five decades can be directly detected by constraining the ice thickness model with multi-temporal glacier inventory data and ice thickness observations (Helfricht et al, submitted). Considering the glacier advance in the 1980s followed by a strong and accelerating retreat since the 1990s, the large difference in calculated apparent mass balances is explained in the imbalanced glacier states with extreme ratios between surface mass balance and surface elevation changes. In terms of the different glacier inventories, GI1 marks the time before glacier advance, at time of GI2 glaciers already started to lose mass, and ice flux has been strongly reduced towards GI3.

For the HF-model we performed a cross-validation between modelled and measured point ice thickness, which indicates model errors of $25-36 \%$. These errors refer to the overall uncertainty in the individual point ice thickness.

The calibration also showed that applying different parameter sets for the HF-model resulted in different mean ice thickness, but the spatial ice thickness distribution remains similar, because it strongly depends on glacier extent and surface slope. Thus, the spatial patterns of potential lake locations between different model solutions was found to be nearly constant and only the resulting overdeepenings changed in depth and, thus, volume. However, as we could show above, even though the HF-method was trained to reproduce the measured ice thickness, this did not lead to a significant advance in the prediction of the subglacial topography and subglacial depressions.

The application of $\mathrm{MC}$ for identification of potential subglacial depressions revealed a comparable number of locations, but a poor match with modelling results. This is attributed to the highly subjective procedure of applying $\mathrm{MC}$ and interpreting aerial images accordingly. In contrast to the models, manual identification by MCs delivers potential locations, but no information about the size or depth of the potential depressions. 
Modelling results produce a total of $5.1-10.4 \mathrm{~km}^{2}$ of potential lake area underneath the current glacier extent of Austria. Despite the large spread, the modelled lake surface is very high in relation to the lake area that has formed since the LIA and the remaining glacier area. We showed that since the end of the Little Ice Age (LIA) almost $3 \mathrm{~km}^{2}$ of new lakes have emerged (Figure 5). This number could be slightly higher taking into account that some lakes have already disappeared during this time, and therefore were not detected with the procedure applied. During the same time, two-thirds of the ice extent at maximum during the mid-19 ${ }^{\text {th }}$ century (glacier area 1850: $940 \mathrm{~km}^{2}, 2015: 328 \mathrm{~km}^{2}$ ) has disappeared. The simple ratio-based estimation revealed that a similar, but smaller total area of potential new lakes could emerge. Despite the large uncertainties in the future evolution of the glaciers, the recent observations of current retreat rates may indicate a fast decline of glaciers in Austria until the mid-2 ${ }^{\text {st }}$ century, we consider the approximation more realistic than to the models.

\subsection{Conclusion}

We conclude that

(1) A total area between 4 and $10 \mathrm{~km}^{2}$ may evolve into potential new lakes from the current glacier surface.

(2) Considering a mean lake size of 12,00o, based on the field observations, between 200 and 260 new lakes may appear between 2015 and 2100. The models predict a mean lake size of 50,000 $\mathrm{m}^{2}$ and between 130 and 230 new lakes in the future.

(3) The applied modelling approach contains large uncertainties. The models do not represent the subglacial topography with great accuracy and reliability. Uncertainties of the modelling approach are difficult to assess and models provide only limited possibilities for calibration and adaptation.

(4) A detailed localization of future glacier lakes is difficult and requires more field evaluation. The modelling results therefore only deliver a rough estimation of the total size of potential new lakes. Locations that are predicted in both models have the greatest potential for correct prediction and should be verified in the field.

(5) The application of the MC for identification of potential subglacial depressions revealed a comparable number of locations of future lakes, but a poor match with modelling results. Additionally, no information about size or depth of the potential depressions is provided. 
Otto et al. (2019): Futurelakes - Final Report

\section{ASSESSMENT OF LAKE LIFETIME}

\section{Publications:}

Otto et al. (2016). What goes in comes out, does it? Proglacial lake sedimentation patterns and trapping efficiency derived from ground penetrating radar and echo sounding sounding. Geophysical Research Abstracts. Vol. 18, EGU2016-3467, 2016, EGU General Assembly 2016. (Poster)

Otto et al. (in preparation): Sediment delivery into recently formed proglacial lakes. Insights from lake Sulzsee, Hohe Tauern, Austria.

Within the alpine sediment cascade glacial lakes represent important sediment sinks often located in the upper reaches of the cascade. Formation of glacial lakes significantly reduces sediment output from glaciated watersheds thus impacting on proglacial sediment budgets and downstream fluvial sediment availability. The reduction of flow velocity when entering a lake causes sedimentation and formation of delta and lake deposits. Accommodation space (i.e. lake volume), grain size and flow velocity are the dominant parameters determining the amount of material deposited within or transferred through the lake. The ratio between sediment amount delivered to the lake and exported from the lake is defined as trapping efficiency (TE). TE is influenced by the geometry of the lake, the retention time of water in the lake and runoff characteristics (Verstraeten and Poesen, 200o). It directly determines the lifetime of the lake before it is filled in with sediments. TE is frequently studied and quantified for reservoir lakes and non-glacial lakes, but little information on trapping efficiency of proglacial lakes exist (Kummu et al., 2010; Mulu and Dwarakish, 2015). Lake lifetime is a function of sediment delivery, trapping efficiency, and lake volume. The time during which glacier lakes exist as water bodies determines how long they can function as sediment sinks, hydrological storage, and as potential source for natural hazards. Therefore, this information is vital for the management of glacier lakes as landscape elements.

We chose a recently evolved lake in Obersulzbachtal, Hohe Tauern range, to study effects of lake sedimentation in detail for the assessment of potential lake lifetime and the quantification of sediment delivery into glacier lakes. Since the late 1990's, a proglacial lake developed following the retreat of the Obersulzbachkees glacier in the Austrian Alps (Figure 15). The lake formed behind a bedrock ridge at an altitude of 2,200 $\mathrm{m}$ covering an area of $165,000 \mathrm{~m}^{2}$. Since its formation, the lake is monitored by the local authorities (Land Salzburg HYDRO) that operate two runoff-monitoring stations at the lake outlet. 


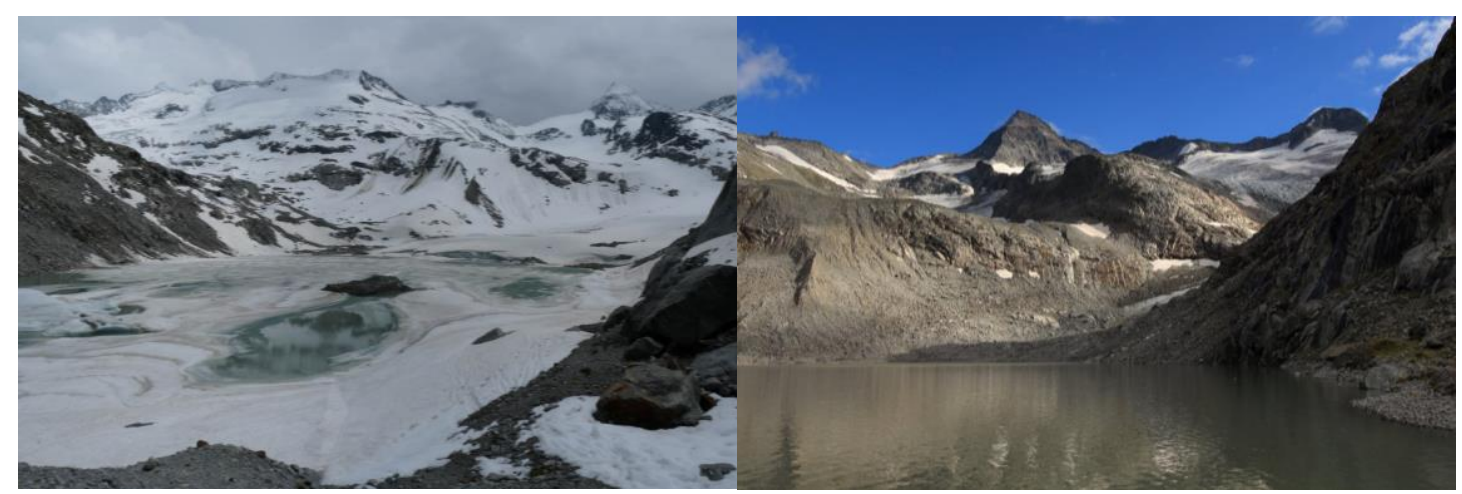

Figure 15 Lake Sulzsee in Obersulzbachtal, Hohe Tauern. Left: Lake position in 2009 (spring). Icebergs and supraglacial debris is observable on the frozen lake surface. The glacier front is still in contact with the lake, observable in the distal right part of the lake. Right: Lake position in 2018 (summer). The glacier terminus retreated from lake area completely.

We investigated lake morphology and lake sedimentation using ground-penetrating radar (GPR), echo sounding and sub-bottom profiling (SBB) data to quantify changes in lake volume and sediment deposits within the lake. Lake bathymetry was measured in 2009, 2015 and 2018. GPR data was collected in winter 2016 on the frozen lake surface and in summer 2017 from a boat using different antenna frequencies (100/200 MHz). Sub-bottom profiling was performed within a pilot campaign in summer 2018.

Lake morphology is best described as a bowl-shaped hollow with a maximum length of $650 \mathrm{~m}$ and a width of $460 \mathrm{~m}$. The bowl has a flat bottom and asymmetrically shaped distal (close to outlet) and proximal (close to glacier) flanks with a steeper distal slope of more than $50^{\circ}$ inclination and a gentler proximal slope following an extended shallow shore area. The maximum depth of the lake decreased from $42.5 \mathrm{~m}$ to $35.6 \mathrm{~m}$ between 2009 and 2015 , depicting lake sedimentation processes. This development continued into 2018 showing a further reduction in lake depth on the order of 1-3 $\mathrm{m}$ (Figure 16).

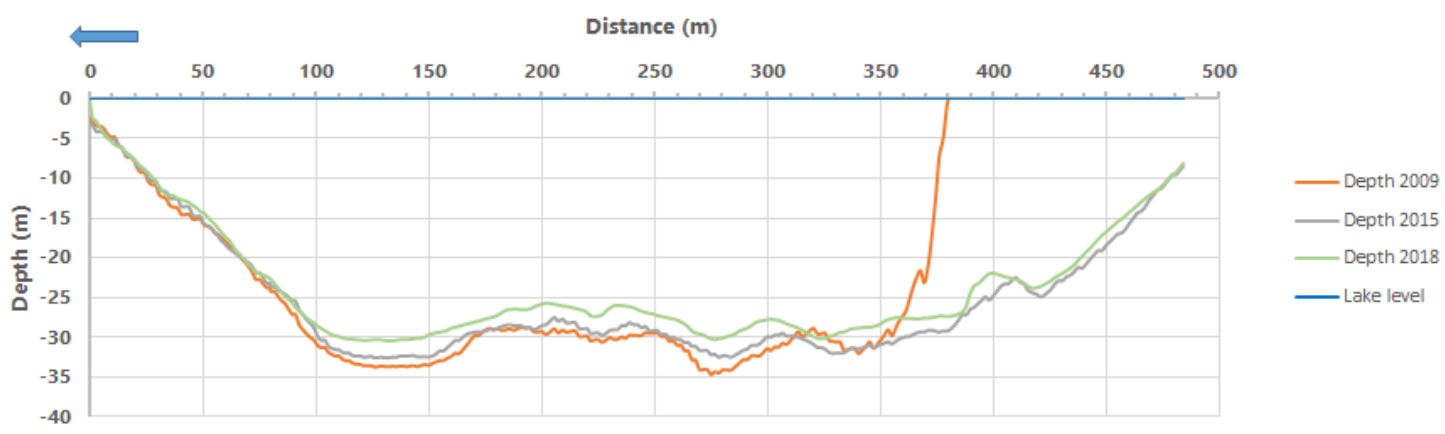

Figure 16 Longitudinal cross section of the lake bottom of lake Sulzsee, Obersulzbachtal, Austria, derived from repeated echo sounding and SBB profiling between 2009 and 2018. Reference lake level is $2202 \mathrm{~m}$.

GPR measurements within the delta area enabled to quantify sediment volumes in the proximal part of the lake (Figure 17). The bedrock interface beneath the delta sediments is 
clearly detectable in the GPR data. Furthermore, dipping structures and single reflectors document the composition of the delta infill. Dipping structures indicate foreset beds and single reflectors may represent deposition of single boulders from supraglacial debris. Sediment depositions within delta reaches maximum values of 20 meters. A total volume of approximately $600.000 \mathrm{~m}^{3}$ was derived from interpolation of bedrock structures within the delta area. This represents an average sediment input of roughly $100.000 \mathrm{t} \mathrm{yr}^{-1}$ of glacial deposits.

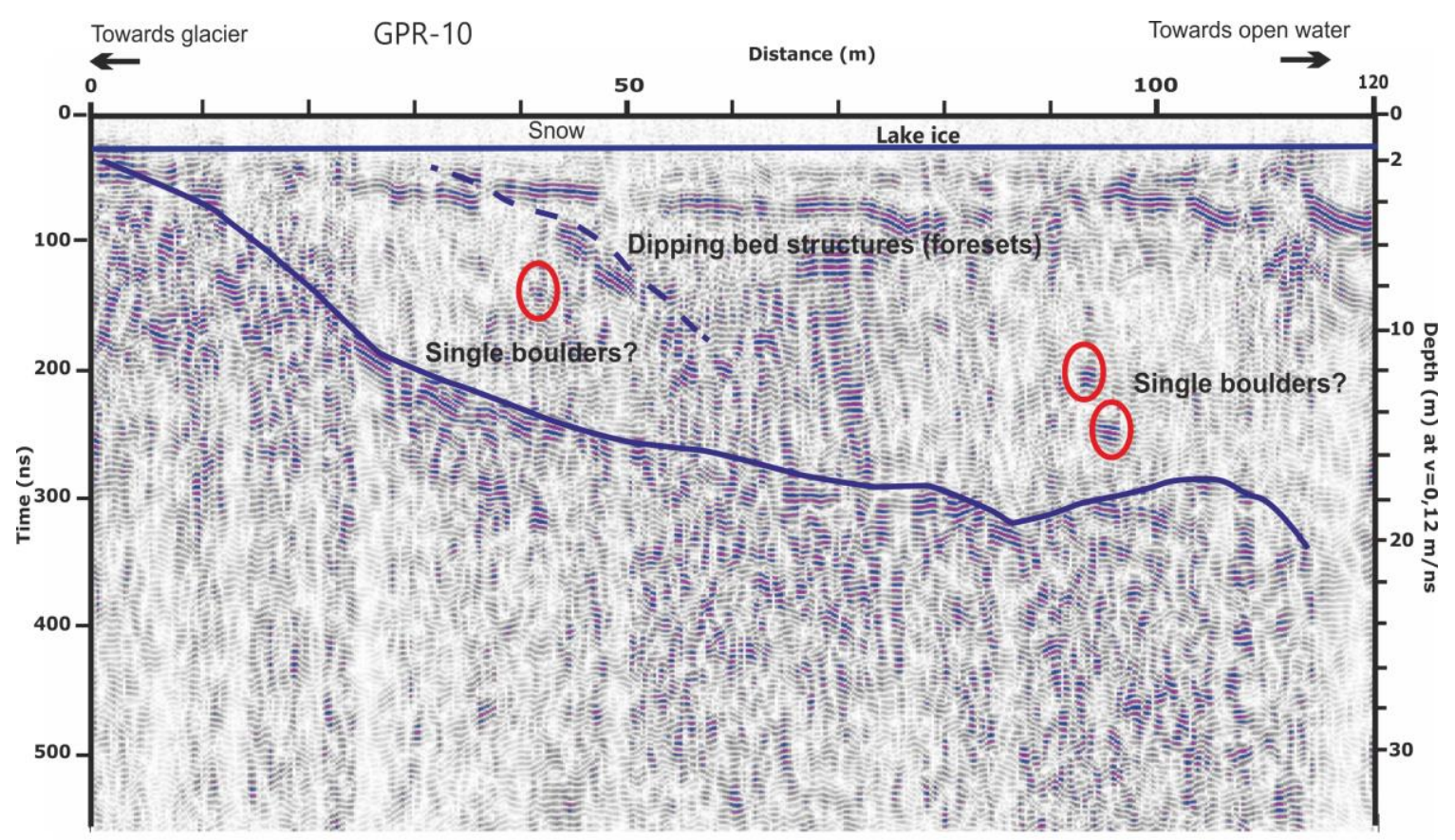

Figure 17 Radargram of delta area at lake Sulzsee, showing the declining bedrock interface clearly visible underneath the sediment filling of the lake. Single boulders and inclined linear structure in the reflection pattern indicate delta type sedimentation. Data was acquired using a $100 \mathrm{MHz}$ antenna and a $1 \mathrm{~m}$ trace interval.

Sediment delivery into the open water of the lake area can be assessed by comparing bathymetry data from 2009 and 2015 (Figure 18). Lake bottom changes show two directions, positive and negative. Rise in lake bottom is associated with sediment deposition. Deposition of 1-10 meters can be observed in the central part of the lake and near the outlet of a small creek from the eastern slope (marked with 1 in Figure 18). Towards the proximal part of the lake, the highest rise of the lake bottom can be observed, clearly related to sediment input from the southern tributary (marked with 2 in Figure 18) draining the glaciers, which delivers most of the water and sediment into the lake. This also reflects delta growth at the lake bottom. Negative changes of the lake bottom are interpreted as melting of sediment-covered ground ice (dead ice) located at the lake bottom close to the 2009 glacier terminus and within the lateral moraine deposits at the eastern margin of the lake. Sediment deposition in the part of the lake that was released until 2009 is approximately $150.000 \mathrm{~m}^{3}$, representing an input of roughly $25.000 \mathrm{~m}^{3}$ per year. 
Referring to a lake volume of $2.5 \mathrm{M} \mathrm{m}^{3}$, the reconstructed sedimentation volumes would fill the lake in 20 years assuming constant sedimentation rates. This lake lifetime represents a rough estimation only and needs to be specified in more detail. It is assumed that sediment delivery rates decrease with ongoing glacier melt due to increasing distance between glacier front and lake and hence the potential of deposition of coarse sediments outside the lake area.

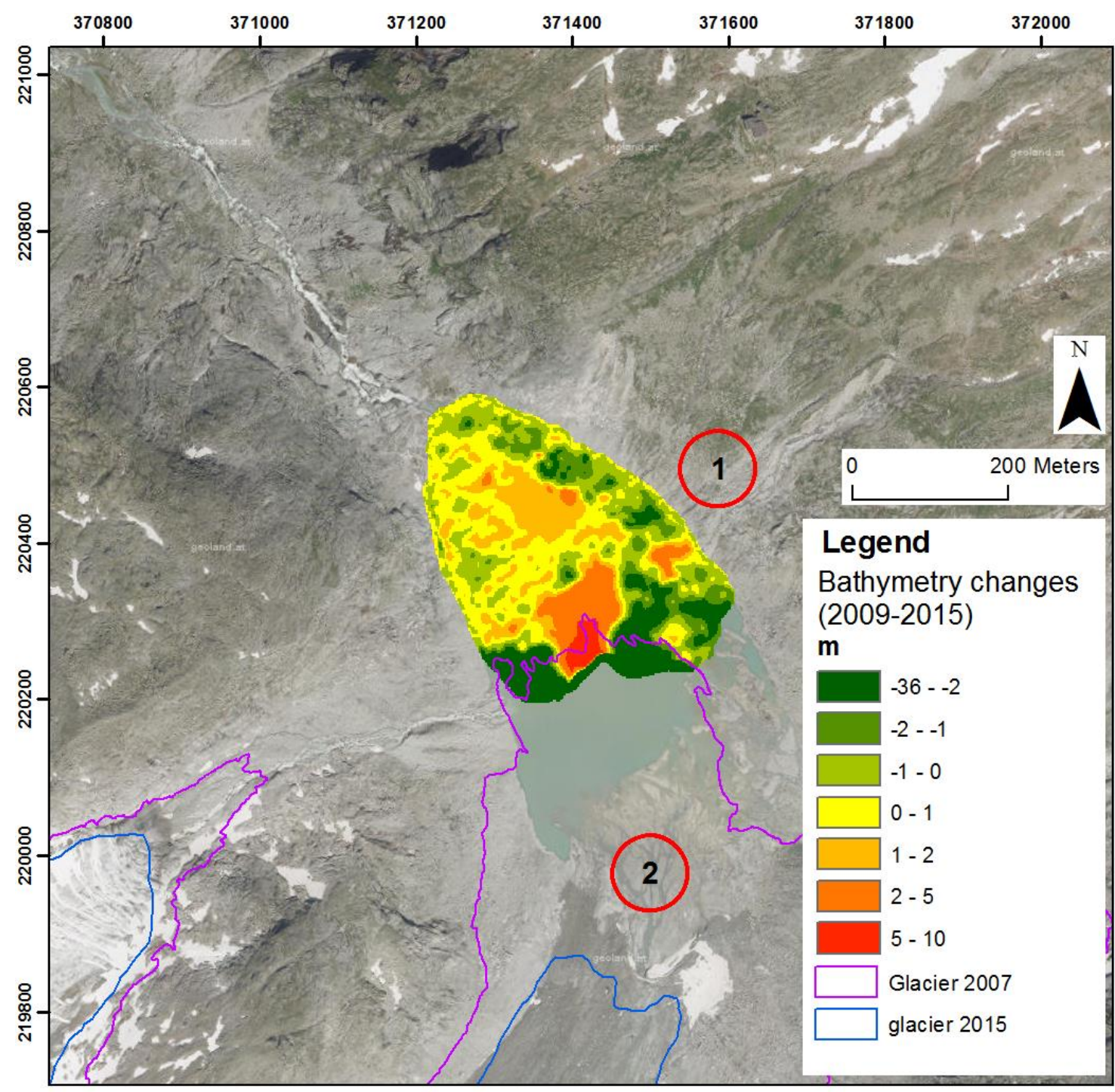

Figure 18 Bathymetry changes between 2009 and 2015 of the lake Sulzsee, Obersulzbachtal, Austria. Lake bottom decrease is interpreted as settling and melt of covered ground ice. Bathymetry increase reflects deposition. 


\section{Dissemination and Outreach}

\section{PUBLICATIONS}

Helfricht, K., Huss, M., Fischer, A. and Otto, J.-C. (submitted). Calibrated ice thickness estimate for all glaciers in Austria. Submitted to: Frontiers in Earth Science.

Buckel, J., Otto, J.C., Prasicek, G. and Keuschnig, M., 2018. Glacial lakes in Austria Distribution and formation since the Little Ice Age. Global and Planetary Change, 164, 3951. /10.1016/j.gloplacha.2018.03.003.

Otto, J.-C., 2018. Proglacial lakes in high mountain environments. In: Heckmann, T and Morche, D. (eds.): Geomorphology of Proglacial Systems - Landform and Sediment Dynamics in Recently Deglaciated Alpine Landscapes. Chapter 5.3. Geography of the Physical Environment Series, Springer, Heidelberg.

Chandler, B.M.P., Lovell, H., Boston, C.M., Lukas, S., Barr, I.D., Benediktsson, Í.Ö., Benn, D.I., Clark, C.D., Darvill, C.M., Evans, D.J.A., Ewertowski, M.W., Loibl, D., Margold, M., Otto, J.-C., Roberts, D.H., Stokes, C.R., Storrar, R.D., Stroeven, A.P., 2018. Glacial geomorphological mapping: A review of approaches and frameworks for best practice. Earth-Science Reviews, 185, pp. 8o6-846.

Farinotti, D., Brinkerhoff, D. J., Clarke, G. K. C., Fürst, J. J., Frey, H., Gantayat, P., GilletChaulet, F., Girard, C., Huss, M., Leclercq, P. W., Linsbauer, A., Machguth, H., Martin, C., Maussion, F., Morlighem, M., Mosbeux, C., Pandit, A., Portmann, A., Rabatel, A., Ramsankaran, R., Reerink, T. J., Sanchez, O., Stentoft, P. A., Singh Kumari, S., van Pelt, W. J. J., Anderson, B., Benham, T., Binder, D., Dowdeswell, J. A., Fischer, A., Helfricht, K., Kutuzov, S., Lavrentiev, I., McNabb, R., Gudmundsson, G. H., Li, H., and Andreassen, L. M., 2017: How accurate are estimates of glacier ice thickness? Results from ITMIX, the Ice Thickness Models Intercomparison Experiment, The Cryosphere, 11, 949-970, doi:10.5194/tc-11-949-2017.

\section{DATASETS}

Fischer, Andrea; Span, Norbert; Kuhn, Michael; Helfricht, Kay; Stocker-Waldhuber, Martin; Seiser, Bernd; Massimo, Marius; Butschek, Michael (2015): Ground-penetrating radar (GPR) point measurements of ice thickness in Austria. Institute for Interdisciplinary Mountain Research of the Austrian Academy of Sciences, doi:10.1594/PANGAEA.849497

Buckel, J; Otto, J-C (2018): Inventory of glacial lakes in Austria (elevation >170om). https://doi.org/10.1594/PANGAEA.885931

Data Set: Buckel, J; Otto, J-C (2018): The Austrian Glacier Inventory GI 4 (2015) in ArcGis (shapefile) format. https://doi.org/10.1594/PANGAEA.887415 


\section{CONFERENCE PARTICIPATIONS}

Buckel, J., Otto, J.-C., Helfricht, Binder, D., Geilhausen, M., and Keuschnig, M. 2015. Formation and future evolution of glacier lakes in Austria - Research agenda and first results of the FUTURELAKES project. Perth III: Mountains of Our Future Earth . 4-8.Oct. 2015, Perth, Scottland.

Otto et al. (2016). What goes in comes out, does it? Proglacial lake sedimentation patterns and trapping efficiency derived from ground penetrating radar and echo sounding sounding. Geophysical Research Abstracts. Vol. 18, EGU2016-3467, 2016, EGU General Assembly 2016. (Poster)

Buckel et al. (2016). An inventory of high alpine lakes in Austria. Geophysical Research Abstracts. Vol. 18, EGU2016-8251-1, 2016, EGU General Assembly 2016. (Poster)

Helfricht et al. (2016). Ice thickness estimations based on multi-temporal glacier inventories - potential and challenges. Geophysical Research Abstracts, Vol. 18, EGU2016-7616-1, 2016, EGU General Assembly 2016. (Poster)

Otto et al. (2016). Entstehung und zukünftige Entwicklung von Gletscherseen in Österreich, 17. Österreichischer Klimatag 2016, 6.-8. April 2016, Graz.

Otto et al. (2017). Predicting future glacial lakes in Austria using different modelling approaches. Geophysical Research Abstracts, Vol. 19, EGU2017-14016, 2017, EGU General Assembly 2017. (Poster)

Buckel et al. (2017). The formation of glacial lakes in Austria since the Little Ice Age. Geophysical Research Abstracts. Vol. 19, EGU2017-13397, 2017. EGU General Assembly 2017. (Poster)

Prasicek et al. (2017): Hypsometry and the distribution of high-alpine lakes in the European Alps. Geophysical Research Abstracts. Vol. 19, EGU2017-13237, 2017. EGU General Assembly 2017. (Poster)

Fischer et al. (2017): The challenge of monitoring the cryosphere in alpine environments: Prepare the present for the future. Geophysical Research Abstracts. Vol. 19, EGU2017-53631, 2017. EGU General Assembly 2017. (Oral)

Helfricht et al. (2017): Modelling distributed mountain glacier volumes: A sensitivity study in the Austrian Alps. Geophysical Research Abstracts. Vol. 19, EGU2017-7631, 2017. EGU General Assembly 2017 (Poster)

Buckel, et al. (2017): Glacial lake formation in Austria since the Little Ice Age (LIA). 6th International Symposium for Research in Protected Areas 2017. Salzburg, Austria. (Poster)

Otto et al. (2017): Predicting future glacial lakes in Austria - preliminary results. 6th International Symposium for Research in Protected Areas 2017. Salzburg, Austria. (Oral)

Otto et al. (2018): Glacial lakes in Austria - current trends and future development. Geophysical Research Abstracts. Vol. 20, EGU2018-17009, 2018. EGU General Assembly 2018. (Poster) 
Otto et al. (2019): Futurelakes - Final Report

Otto et al. (2018): Semi-automated classification of mountain glacier types. Geophysical Research Abstracts. Vol. 20, EGU2018-6473, 2018. EGU General Assembly 2018. (Poster)

Buckel et al. (2018): New approach to identify filled glacial lakes in high alpine environments. Geophysical Research Abstracts. Vol. 20, EGU2018-6980, 2018. EGU General Assembly 2018. (Poster)

Otto et al. (2018): Neue Gletscherseen in Österreich - Möglichkeiten und Risiko. 19. Österreichischer Klimatag. Aktuelle Klimaforschung in Österreich, 23. - 25. April 2018, Salzburg. (Oral)

Otto, J.-C. and Keuschnig, M. (2018): Future lakes - future potentials. New lakes in Austria following glacier retreat. Forum Alpinum 2018, 4.-6.6.2018, Breitenwang, AT. (Oral)

\section{OUTREACH AND MEDIA}

o6.01.2016: Dokumentation „Gletscherschmelze - Klimawandel im Hochgebirge“ (ARD Alpha, Bayrischer Rundfunk)

26.03.2016: Im Land der neuen Seen (Die Presse)

08.04.2015: Tauzeit in Österreichs Bergen: Seen lösen Gletscher ab (Salzburger Nachrichten)

21.10.2016: WDR Fernsehen: Obersulzbachsee - Der See unter dem Gletscher

21.10.2016: WDR Fernsehen Planet Wissen: Gletscherschmelze - Klimawandel im Hochgebirge (Mit Interview A.Fischer, M. Keuschnig)

04/2017: LIEBLICH ODER BEDROHLICH? GLETSCHERSEEN HABEN VIELE „GESICHTER“, Universum Magazin, 2017.

\#3/2018: Entsteht am Großglockner ein neuer Gletschersee? Heureka, Falter, 2018 


\section{Acknowledgements}

We would like to thank all people that contributed to the success of FUTURELAKES. First of all we are grateful for the opportunity to run the project at all and thank the ÖAW for providing funding and support. Many people contributed to the success of the project with discussions our ideas or help in the field. Johannes Buckel provided substantial support in the first part of the project spending numerous hours mapping glacial lakes, analyzing their distribution and preparing the publication of the results. We thank Milena Kocher, Christopher Hausmann, Lena Grossmann, Celine Van de Hende, Yannick Voithofer, Gerald Griesebner, Jürgen Etzelstorfer, Andreas Lang and others for their support in the field and in office. We also thank Erwin Heine for supplying us with high resolution SBB data from lake Sulzsee. The Alpine rescue club of Neukirchen is thanked for the generous allocation of Doris, the boat at lake Sulzsee. Hans Wiesenegger and the Hydro-Service of Salzburg provided data on past lake bathymetry and showed great interested in our project from early on. Their contribution is highly appreciated. And we also thank Wilfried Haeberli for his devotion to the issue of glacial lakes. He gave a great and inspiring presentation at the University of Salzburg and we had a fruitful and highly motivating discussion on our project. Finally, we thank the reviewers of your publications for helpful comments. 


\section{References}

Andreassen, L.M., Huss, M., Melvold, K., Elvehøy, H., Winsvold, S.H., 2015. Ice thickness measurements and volume estimates for glaciers in Norway. Journal of Glaciology, 61(228), 763-775.

Blass, A., Bigler, C., Grosjean, M., Sturm, M., 2007. Decadal-scale autumn temperature reconstruction back to $\mathrm{AD} 1580$ inferred from the varved sediments of Lake Silvaplana (southeastern Swiss Alps). Quaternary Research, 68, 184-195.

Brückl, E., 1980. Seismische Eisdickenmessungen auf dem Ober- und Untersulzbachkees in den Sommern der Jahre 1973 und 1974, ZAMG, Vienna.

Buckel, J., Otto, J.-C., 2018. The Austrian Glacier Inventory GI 4 (2015) in ArcGis (shapefile) format, Supplement to: Buckel, Johannes; Otto, Jan-Christoph; Prasicek, Günther; Keuschnig, Markus (2018): Glacial lakes in Austria - Distribution and formation since the Little Ice Age. Global and Planetary Change, 164, 3951, https://doi.org/10.1016/j.gloplacha.2018.03.003. PANGAEA.

Buckel, J., Otto, J.C., Prasicek, G., Keuschnig, M., 2018. Glacial lakes in Austria - Distribution and formation since the Little Ice Age. Global and Planetary Change, 164, 39-51.

Carrivick, J.L., Tweed, F.S., 2013. Proglacial lakes: character, behaviour and geological importance. Quaternary Science Reviews, 78(o), 34-52.

Clague, J.J., O'Connor, J.E., 2015. Chapter 14 - Glacier-Related Outburst Floods A2 - Shroder, John F. In: W. Haeberli, C. Whiteman (Eds.), Snow and Ice-Related Hazards, Risks and Disasters. Academic Press, Boston, pp. 487-519.

Colonia, D., Torres, J., Haeberli, W., Schauwecker, S., Braendle, E., Giraldez, C., Cochachin, A., 2017a. Compiling an Inventory of Glacier-Bed Overdeepenings and Potential New Lakes in De-Glaciating Areas of the Peruvian Andes. Water, 9(5), 336.

Colonia, D., Torres, J., Haeberli, W., Schauwecker, S., Braendle, E., Giraldez, C., Cochachin, A., 2or7b. Compiling an Inventory of Glacier-Bed Overdeepenings and Potential New Lakes in De-Glaciating Areas of the Peruvian Andes: Approach, First Results, and Perspectives for Adaptation to Climate Change. Water, $9(5)$.

Cook, S.J., Kougkoulos, I., Edwards, L.A., Dortch, J., Hoffmann, D., 2016. Glacier change and glacial lake outburst flood risk in the Bolivian Andes. Cryosphere, 10(5), 2399-2413.

Cook, S.J., Swift, D.A., 2012. Subglacial basins: Their origin and importance in glacial systems and landscapes. Earth-Science Reviews, 115(4), 332-372.

Emmer, A., Merkl, S., Mergili, M., 2015. Spatiotemporal patterns of high-mountain lakes and related hazards in western Austria. Geomorphology, 246, 602-616.

Farinotti, D., Brinkerhoff, D.J., Clarke, G.K.C., Fürst, J.J., Frey, H., Gantayat, P., Gillet-Chaulet, F., Girard, C., Huss, M., Leclercq, P.W., Linsbauer, A., Machguth, H., Martin, C., Maussion, F., Morlighem, M., Mosbeux, C., Pandit, A., Portmann, A., Rabatel, A., Ramsankaran, R., Reerink, T.J., Sanchez, O., Stentoft, P.A., Singh Kumari, S., van Pelt, W.J.J., Anderson, B., Benham, T., Binder, D., Dowdeswell, J.A., Fischer, A., Helfricht, K., Kutuzov, S., Lavrentiev, I., McNabb, R., Gudmundsson, G.H., Li, H., Andreassen, L.M., 2017. How accurate are estimates of glacier ice thickness? Results from ITMIX, the Ice Thickness Models Intercomparison eXperiment. The Cryosphere, 11(2), 949-970.

Farinotti, D., Huss, M., Bauder, A., Funk, M., Truffer, M., 2009. A method to estimate the ice volume and icethickness distribution of alpine glaciers. Journal of Glaciology, 55(191), 422-430.

Fischer, A., Seiser, B., Stocker Waldhuber, M., Mitterer, C., Abermann, J., 2015a. Tracing glacier changes in Austria from the Little Ice Age to the present using a lidar-based high-resolution glacier inventory in Austria. The Cryosphere, 9(2), 753-766.

Fischer, A., Span, N., Kuhn, M., Helfricht, K., Stocker-Waldhuber, M., Seiser, B., Massimo, M., Butschek, M., 2015b. Ground-penetrating radar (GPR) point measurements of ice thickness in Austria. PANGAEA.

Frey, H., Haeberli, W., Linsbauer, A., Huggel, C., Paul, F., 2010a. A multi-level strategy for anticipating future glacier lake formation and associated hazard potentials. Natural Hazards and Earth System Science, 10(2), 339-352.

Frey, H., Huggel, C., Paul, F., Haeberli, W., 2010b. Automated detection of glacier lakes based on remote sensing in view of assessing associated hazard potentials. Proceedings 1oth international sympsoium on high mountain remote sending cartography, 23-30. 
Frey, H., Machguth, H., Huss, M., Huggel, C., Bajracharya, S., Bolch, T., Kulkarni, A., Linsbauer, A., Salzmann, N., Stoffel, M., 2013. Ice volume estimates for the Himalaya-Karakoram region: evaluating different methods. The Cryosphere Discuss., 7(5), 4813-4854.

Frey, H., Machguth, H., Huss, M., Huggel, C., Bajracharya, S., Bolch, T., Kulkarni, A., Linsbauer, A., Salzmann, N., Stoffel, M., 2014. Estimating the volume of glaciers in the Himalayan-Karakoram region using different methods. The Cryosphere, 8(6), 2313-2333.

Gardelle, J., Arnaud, Y., Berthier, E., 2011. Contrasted evolution of glacial lakes along the Hindu Kush Himalaya mountain range between 1990 and 2009. Global and Planetary Change, 75(1-2), 47-55.

Haeberli, W., Buetler, M., Huggel, C., Friedli, T.L., Schaub, Y., Schleiss, A.J., 2016. New lakes in deglaciating high-mountain regions - opportunities and risks. Climatic Change, 139(2), 201-214.

Haeberli, W., Hölzle, M., 1995. Application of inventory data for estimating characteristics of and regional climate effects on mountain glaciers: A pilot study with the European Alps Annals of Glaciology, 21, 206-212.

Helfricht, K., Huss, M., Fischer, A., Otto, J.C., submitted. Calibrated ice thickness estimate for all glaciers in Austria. . Frontiers in Earth Science. .

Huss, M., Farinotti, D., 2012. Distributed ice thickness and volume of all glaciers around the globe. Journal of Geophysical Research: Earth Surface, $117\left(\mathrm{~F}_{4}\right)$, n/a-n/a.

Kapitsa, V., Shahgedanova, M., Machguth, H., Severskiy, I., Medeu, A., 2017a. Assessment of evolution and risks of glacier lake outbursts in the Djungarskiy Alatau, Central Asia, using Landsat imagery and glacier bed topography modelling. Nat. Hazards Earth Syst. Sci., 17(10), 1837-1856.

Kapitsa, V., Shahgedanova, M., Machguth, H., Severskiy, I., Medeu, A., 2017b. Assessment of evolution and risks of glacier lake outbursts in the Djungarskiy Alatau, Central Asia, using Landsat imagery and glacier bed topography modelling. Nat. Hazards Earth Syst. Sci., 17(10), 1837-1856.

Kummu, M., Lu, X.X., Wang, J.J., Varis, O., 2010. Basin-wide sediment trapping efficiency of emerging reservoirs along the Mekong. Geomorphology, 119(3-4), 181-197.

Larsen, D.J., Miller, G.H., Geirsdóttir, Á., Thordarson, T., 2011. A 3000-year varved record of glacier activity and climate change from the proglacial lake Hvítárvatn, Iceland. Quaternary Science Reviews, 30(19-20), 2715-2731.

Leemann, a., Niessen, F., 1994. Varve formation and the climatic record in an Alpine proglacial lake: calibrating annually- laminated sediments against hydrological and meteorological data. The Holocene, 4, 1-8.

Linsbauer, A., Frey, H., Haeberli, W., Machguth, H., Azam, M.F., Allen, S., 2016a. Modelling glacier-bed overdeepenings and possible future lakes for the glaciers in the Himalaya-Karakoram region. Annals of Glaciology, 57(71), 119-130.

Linsbauer, A., Frey, H., Haeberli, W., Machguth, H., Azam, M.F., Allen, S., 2016b. Modelling glacier-bed overdeepenings and possible future lakes for the glaciers in the Himalaya-Karakoram region. Annals of Glaciology, 57(71), 119-130.

Linsbauer, A., Paul, F., Haeberli, W., 2012a. Modeling glacier thickness distribution and bed topography over entire mountain ranges with GlabTop. Journal of Geophysical Research: Earth Surface, $117\left(\mathrm{~F}_{3}\right)$, n/a-n/a.

Linsbauer, A., Paul, F., Haeberli, W., 2012b. Modeling glacier thickness distribution and bed topography over entire mountain ranges with GlabTop: Application of a fast and robust approach. Journal of Geophysical Research: Earth Surface, $117\left(\mathrm{~F}_{3}\right)$, Fo3007.

Linsbauer, A., Paul, F., Hoelzle, M., Frey, H., Haeberli, W., 2009. The Swiss Alps Without Glaciers - A GIS-based Modelling Approach for Reconstruction of Glacier Beds. In: R. Purves, S. Gruber, R. Straumann, T. Hengl (Eds.), Proceedings of Geomorphometry 2009. University of Zürich, Zürich, pp. 243-247.

Livingstone, S.J., Clark, C.D., Woodward, J., Kingslake, J., 2013. Potential subglacial lake locations and meltwater drainage pathways beneath the Antarctic and Greenland ice sheets. The Cryosphere, 7(6), 1721-1740.

Maisch, M., Haeberli, W., 1982. Interpretation geomoetrischer Parameter von Spaetglazialgletschern im Gebiet Mittelbuenden, Schweizer Alpen. Physische Geographie, 1, 111-127.

Mergili, M., Müller, J.P., Schneider, J.F., 2013. Spatio-temporal development of high-mountain lakes in the headwaters of the Amu Darya River (Central Asia). Global and Planetary Change, 107, 13-24. 
Messager, M.L., Lehner, B., Grill, G., Nedeva, I., Schmitt, O., 2016. Estimating the volume and age of water stored in global lakes using a geo-statistical approach. Nature communications, 7, 13603-13603.

Mulu, A., Dwarakish, G.S., 2015. Different Approach for Using Trap Efficiency for Estimation of Reservoir Sedimentation. An Overview. Aquatic Procedia, 4, 847-852.

O'Connor, J.E., Costa, J.E., 2004. The World's Largest Floods, Past and Present: Their Causes and Magnitudes, U.S. Geological Survey, Reston, Virginia.

Patton, H., Swift, D.A., Clark, C.D., Livingstone, S.J., Cook, S.J., 2016. Distribution and characteristics of overdeepenings beneath the Greenland and Antarctic ice sheets: Implications for overdeepening origin and evolution. Quaternary Science Reviews, 148, 128-145.

Patton, H., Swift, D.A., Clark, C.D., Livingstone, S.J., Cook, S.J., Hubbard, A., 2015. Automated mapping of glacial overdeepenings beneath contemporary ice sheets: Approaches and potential applications. Geomorphology, 232, 209-223.

Paul, F., Linsbauer, A., 2012. Modeling of glacier bed topography from glacier outlines, central branch lines, and a DEM. International Journal of Geographical Information Science, 26(7), 1173-119o.

Pelto, M., Capps, D., Clague, J.J., Pelto, B., 2013. Rising ELA and expanding proglacial lakes indicate impending rapid retreat of Brady Glacier, Alaska. Hydrological Processes, 27(21), 3075-3082.

Song, C., Sheng, Y., Ke, L., Nie, Y., Wang, J., 2016. Glacial lake evolution in the southeastern Tibetan Plateau and the cause of rapid expansion of proglacial lakes linked to glacial-hydrogeomorphic processes. Journal of Hydrology, 540(June), 504-514.

Verstraeten, G., Poesen, J., 200o. Estimating trap efficiency of small reservoirs and ponds: methods and implications for the assessment of sediment yield. Progress in Physical Geography, 24(2), 219-251.

Wang, W., Xiang, Y., Gao, Y., Lu, A., Yao, T., 2014. Rapid expansion of glacial lakes caused by climate and glacier retreat in the Central Himalayas. Hydrological Processes, 29(6), 859-874.

Zekollari, H., Huss, M., Farinotti, D., 2018. Modelling the future evolution of glaciers in the European Alps under the EURO-CORDEX RCM ensemble. The Cryosphere Discuss., 2018, 1-38.

Zhang, G., Yao, T., Xie, H., Wang, W., Yang, W., 2015. An inventory of glacial lakes in the Third Pole region and their changes in response to global warming. Global and Planetary Change, 131(June), 148-157. 